\title{
Koncepcija općenarodne obrane i društvene samozaštite - militarizam samoupravnoga socijalizma
}

\author{
DAVOR MARIJAN \\ Hrvatski institut za povijest \\ Zagreb, Hrvatska \\ dmarijan66@gmail.com
}

Koncepcija općenarodne obrane i društvene samozaštite, kako se od sredine 1970ih zvao jugoslavenski obrambeno-zaštitni sustav, počela se provoditi nakon invazije zemalja Varšavskoga ugovora na Čehoslovačku u kolovozu 1968. Jugoslavenski komunisti smatrali su da se takvoj, iznenadnoj i uspješnoj agresiji mogu učinkovito suprotstaviti samo organiziranim angažmanom svih raspoloživih potencijala društva na temelju svojega revolucionarnog iskustva i promišljanja klasika marksizma o naoružanome narodu. Tako je počela nastajati obrambena koncepcija koja je osjetno opteretila društvo, povećala ionako velike financijske izdatke za vojsku i potaknula militarizaciju društva. Premda je istovremeno s obrambenom funkcijom problematizirana i funkcija sigurnosti društva pod imenom društvena samozaštita, pravi poticaj za njezino teorijsko i praktično uobličavanje dao je upad naoružane skupine Feniks u Jugoslaviju u ljeto 1972. No do koliko-toliko učinkovite fuzije tih dvaju zaštitnih kompleksa doći će tek 1979. osnivanjem komiteta za općenarodnu obranu i društvenu samozaštitu, koji su u obrambeno-zaštitnom sustavu trebali osigurati rukovodeću ulogu Saveza komunista Jugoslavije.

Ključne riječi: Jugoslavija; Hrvatska; Savez komunista Jugoslavije; obrana, sigurnost; militarizam

Povodom četrdesetogodišnjice Oružanih snaga Socijalističke Federativne Republike Jugoslavije (SFRJ) u drugoj polovini 1980-ih u organizaciji Saveznoga sekretarijata za narodnu obranu napisana je interna povijest Jugoslavenske narodne armije (JNA). ${ }^{1} \mathrm{U}$ dijelu koji se bavi koncepcijom općenarodne obrane (ONO) i društvene samozaštite (DSZ) tvrdi se da je 1958. prihvaćanjem Doktrine općenarodnog rata počelo razdoblje općenarodne obrane, koja

* Rad je nastao u sklopu projekta Rat, žrtve, nasilje i granice slobode u hrvatskoj povijesti 20. stoljeća - WarVic (IP-2019-04-6673), koji financira Hrvatska zaklada za znanost.

1 O pobudama za pisanje i smislu edicije u vidu predgovora napisao je tekst admiral Branko Mamula, koji je od 1982. do 1988. bio savezni sekretar za narodnu obranu SFRJ. MAMULA, „Predgovor ediciji ‘Razvoj oružanih snaga SFRJ 1945-1989””, 5-31. 
se do 1968. teorijski razrađivala i počela praktično primjenjivati. ${ }^{2}$ Međutim, dovoljno je dokaza da se o stvarnoj primjeni koncepcije općenarodne obrane može govoriti tek od 1968., nakon invazije zemalja Varšavskoga ugovora na Čehoslovačku. Obrana je dotad bila domena federacije u kojoj je JNA bila neprikosnovena i ta je „idila” trajala do kolovoza 1968., što potvrđuju rečenice Republičkoga sekretarijata za narodnu obranu Socijalističke Republike Hrvatske (SRH) iz ožujka 1969. godine.

„Orijentacija na pasivnu ulogu civilnog sektora u ratu i nedosljednost u primjeni koncepcije općenarodne obrane dominirali su u praktičnom provođenju obrambenih priprema."3

\section{Nastanak i provedba koncepcije općenarodne obrane}

Učinkovita invazija oružanih snaga dijela zemalja članica Varšavskoga ugovora na Čehoslovačku u noći 20./21. kolovoza 1968. imala je ozbiljne posljedice za svijet komunizma, a Jugoslaviju je doslovno zatekla. Ona se nakon pomirenja sa Savezom Sovjetskih Socijalističkih Republika (SSSR) sredinom 1950-ih ponovno okrenula prema „prirodnom” neprijatelju - zemljama Zapa$\mathrm{da}$, iako se formalno nije vratila $\mathrm{u}$ istočni blok. Invazija je dovela u pitanje cijeli sustav obrane i mirnodopski raspored JNA, koja je upravo te godine okončala novi preustroj, kojim je glavninu snaga razmjestila prema nekomunističkim susjedima: Italiji, Austriji i Grčkoj. Orijentacija prema Zapadu utjecala je i na razmještaj materijalno-tehničkih resursa bitnih za vođenje rata u istočnim dijelovima zemlje. Događaji u Čehoslovačkoj zatekli su Jugoslaviju bez ozbiljnih snaga prema zemljama članicama Varšavskoga ugovora. Malobrojne mirnodopske snage JNA prema Mađarskoj i Bugarskoj žurno su prevedene u viši stupanj borbene spremnosti, a Rumunjska u tom trenutku nije bila sigurnosna prijetnja. Nakon djelomične mobilizacije na ta su područja dovedena jača pojačanja radi zatvaranja smjerova iz kojih su očekivani napadi. Istovremeno su potaknute i mjere za osnivanje partizanskih brigada i teritorijalnih snaga koje su preustrojem JNA 1967. - 1968. svedene na vrlo mali postroj. Poduzete mjere pokazale su velike nedostatke JNA, posebice u njezinoj djelomičnoj mobilizaciji, prvoj takve vrste nakon 1953. godine. Mjere povišene bojne spremnosti u JNA bile su na snazi do 10. listopada 1968. i održavane su kroz vježbu Avala, što je bio način da se prikrije stvarna suština djelovanja i ne shvati kao provociranje SSSR-a. ${ }^{4}$

2 NIKEZIĆ, „Koncepcija, doktrina i sistem opštenarodne odbrane u periodu od 1958. do 1968. godine", 207, 299-300.

3 HR-SVA-RSNO, RSNO SRH, ožujak 1969., Izvještaj o provođenju obrambenih priprema na teritoriji SRH u 1968. g., 1 .

4 Savremena vojno-politička situacija u svetu i vojno-strategijski položaj naše zemlje, II uprava GŠ JNA, str. pov. 1 od 4. 1. 1967., 38-39 (preslika u posjedu autora); HR-HDA-1220-CK SKH, D-SP-531: CKSKJ, Informacija o zajedničkoj sednici, str. pov. br. 03-14/1 od 6. 9. 1968.; 
Posljedica invazije na jugoslavensku obrambenu politiku bila je velika i dugoročna jer je potaknula primjenu koncepcije općenarodne obrane, odnosno rječnikom socijalističkoga samoupravljanja - podruštvljavanje obrane. ${ }^{5}$ Na sjednici Predsjedništva i Izvršnoga komiteta Centralnoga komiteta Saveza komunista Jugoslavije (CK SKJ) 21. kolovoza 1968. na Brijunima raspravljalo se o stanju koje je izazvala netom izvedena invazija. Jugoslavija je u tom trenutku bila u relativno nepovoljnom političkom stanju, gospodarska reforma bila je neučinkovita, a dva mjeseca ranije potresle su ju demonstracije studenata nezadovoljnih stanjem u društvu. ${ }^{6}$ Koliko je invazija na Čehoslovačku zabrinula jugoslavenske komuniste vidljivo je i iz potrebe da se o novim političkim implikacijama u svijetu komunizma javno očituje i CK SKJ na 10. sjednici 23. kolovoza 1968. U Rezoluciji sjednice istaknuto je da SKJ ne priznaje nikome pravo da se vojnom intervencijom i bilo kakvim oblicima pritiska samovoljno miješa u unutarnji razvoj i poslove neovisne zemlje te da je Jugoslavija „kao i uvek do sada” odlučna da „svim snagama i sredstvima” brani svoju neovisnost, revoluciju i svoj socijalistički put. „Zalagaćemo se za dalje jačanje obrambene sposobnosti i bezbednosti naše zemlje. To je stvar svih građana, svih naroda i narodnosti naše socijalističke zajednice."

Na sjednicama saveznoga partijskog vrha u kolovozu i rujnu 1968. provođenje koncepcije općenarodne obrane dobilo je prioritet jer je bilo očito da se dotad nije realizirala zato što ju nije prihvatila JNA. ${ }^{8} \mathrm{Na}$ sjednici proširenoga Biroa Predsjedništva CK SKJ 3. rujna 1968. ocijenjeno je da koncept općenarodne obrane,

„[...] koji je u načelu ranije prihvaćen, nije u potpunosti i dosledno razrađivan i sprovođen. Zbog toga su Predsedništvo i Izvršni komitet usvojili stav da se najhitnije pristupi razradi koncepta opštenarodne odbrane. Na osnovu toga Biro je doneo zaključke u pogledu daljeg rada odgovornih političkih i drugih organa na razradi i sprovođenju u životu koncepta opštenarodne odbrane".9

Na sjednicama partijskih i državnih rukovodstava zaključeno je da JNA nije u stanju sama voditi rat jer je organizacija obrane oslonjena isključivo na operativnu vojsku uska i nedjelotvorna. Zaključak je bio dalekosežan i označavao je pobjedu gledišta prema kojem je obrambenu organizaciju trebalo temeljiti na iskustvima iz rata i revolucije, odnosno uzeti u obzir civilne

NOVOSEL, „Rad Saveznog sekretarijata za narodnu odbranu od 1968. do 1985. godine”, 315; RADIĆ, „Vežba Avala - Jugoslovenska odbrana od Varšavskog pakta 1968. godine”, 87-104; KLASIĆ, Jugoslavija i svijet 1968., 407-416.

5 Podruštvljavanje je kolektivistička mjera čija je svrha uključivanje što većega broja osoba u bavljenje određenom problematikom bez obzira na stručnost. Definicija podruštvljavanja u: TUBIĆ, Enciklopedijski rječnik marksističkih pojmova, 360.

6 KLASIĆ, Jugoslavija i svijet 1968., 407-409.

7 Deseta sednica CK SKJ, 11-12.

8 KLASIĆ, Jugoslavija i svijet 1968., 416-417.

9 HR-HDA-1220-CK SKH, D-SP-531: Zaključci proširenog Biroa Predsjedništva CKSKJ, str. pov. br. 02-20/2 od 5. 9. 1968. 
strukture i partizansku komponentu u organiziranju oružane sile i odabiru načina vođenja rata. ${ }^{10} \mathrm{Na}$ sjednici Predsjedništva i Izvršnoga komiteta CK SKJ održanoj 2. rujna 1968. na Brijunima zaključeno je da su se ranije „pretpostavke eventualnog napada na našu zemlju” temeljile na „mogućnosti napada sa Zapada tako da su zemlje istočnih suseda tretirane kao zaleđe i oslonac. U izmenjenoj situaciji postoji i mogućnost napada i sa druge strane". "Takav zaključak svakako pokazuje da je unatoč politici nesvrstavanja državno vodstvo demokratski Zapad smatralo glavnim neprijateljem, a komunistički Istok saveznikom. Dakle, od kraja kolovoza 1968. računalo se da je agresija na SFRJ moguća i s Istoka, a ne kao što se tada mislilo isključivo sa Zapada. Osim toga, dotad je sva pozornost bila usmjerena na opći nuklearni rat, a zanemarena je mogućnost lokalnih ratova. ${ }^{12}$

Na temu obrane i 3. rujna 1968., ponovno na Brijunima, održana je proširena sjednica Biroa Predsjedništva CK SKJ s predsjednicima republičkih centralnih komiteta, predsjednikom Savezne skupštine i predsjednikom Saveznoga izvršnog vijeća. Rezultat razgovora na te dvije sjednice bilo je donošenje 19 zaključaka o općenarodnoj obrani. ${ }^{13}$ Dio zaključaka bio je u formi partijskih smjernica.

„U cilju što brže realizacije nekih bitnih principa opštenarodne odbrane neophodno je odmah pristupiti obrazovanju političkih rukovodstava za sprovođenje priprema svenarodne odbrane - vojno-političkih komiteta u Federaciji, republikama i opštinama.

Inicijativu za njihovo obrazovanje treba da preuzmu predsedništva i izvršni komitet centralnih komiteta Saveza komunista republike, a u opštinama rukovodstva Saveza komunista.

Na nivou Federacije prošireni Biro Predsedništva Centralnog komiteta Saveza komunista Jugoslavije preuzima na sebe odgovornost opšteg političkog rukovodstva svih aktivnosti u zemlji usmerenih na razradu i primenu principa svenarodne odbrane. Za neposredno operativno rukovođenje svim pripremama u ostvarivanju principa opštenarodne odbrane biće i na nivou u najskorije vreme obrazovan vojni komitet."14

Svi vojno-politički komiteti trebali su biti „autoritativni politički organi sastavljeni od najodgovornijih političkih rukovodilaca i iskusnih aktivnih i

10 HR-HDA-1220-CK SKH, D-SP-531: CKSKJ, Informacija o zajedničkoj sednici, str. pov. br. 03-14/1 od 6. 9. 1968.; KLASIĆ, Jugoslavija i svijet 1968., 417-420.

11 HR-HDA-1220-CK SKH, D-SP-531: CKSKJ, Informacija o zajedničkoj sednici, str. pov. br. $03-14 / 1$ od 6. 9. 1968.

12 HR-SVA-RSNO, materijali sa sjednice SNO SRH od 12. 11. 1968.: Zapisnik sa sjednice SNO SRH od 3. 9. 1968.; HR-SVA-RSNO, RSNO SRH, ožujak 1969., Izvještaj o provođenju obrambenih priprema na teritoriji SRH u 1968. g., 1-4.

13 HR-HDA-1220-CK SKH, D-SP-531: Predsedništvo CKSKJ, Zaključci proširenog Biroa PCKSKJ, str. pov. br. 02-20/2 od 5. 9. 1968.

14 HR-HDA-1220-CK SKH, D-SP-531: PCKSKJ, Zaključci proširenog Biroa PCKSKJ, str. pov. br. $02-20 / 2$ od 5. 9. 1968. 
rezervnih starešina” JNA, uz određeni broj sposobnih mladih kadrova. Naglašena je važnost osnivanja vojno-političkih komiteta u republikama kao tijela za rukovođenje svim pripremama na svojem području i koji su u slučaju „neposredne opasnosti od agresije ili same agresije” trebali prerasti u „glavne štabove socijalističkih republika”. Prvi, i reklo bi se prioritetni, zadatak vojno-političkih komiteta svih društveno-političkih zajednica i organizacija ${ }^{15}$ bio je da u suradnji sa svim nadležnim stručnim i drugim tijelima i organizacijama, posebice s tijelima JNA, počnu razrađivanje koncepcije općenarodne obrane i utvrđivanje svojih konkretnih zadataka u njezinoj pripremi. Komunisti u JNA pozvani su da ulože posebne napore u usuglašavanje i konkretni rad na načelima općenarodne obrane. ${ }^{16} \mathrm{Na}$ sjednici održanoj dan prije zaključeno je da se na poslovima obrane angažira „čitav partijski aktiv Jugoslavije” $\mathrm{i}$ da se on smatra mobiliziranim. ${ }^{17} \mathrm{U}$ zaključcima od 3. rujna naglašena je obveza SKJ da organizira i vodi općenarodnu obranu. „Svaki član Saveza komunista treba da se smatra mobilisanim u svakoj situaciji kada zemlji zapreti opasnost od agresije spolja." Slična je obveza određena kao stalan zadatak svih tijela, organizacija, radnih ljudi i građana, a u posebnoj točki rečeno je da svi narodi i narodnosti u provedbi općenarodne obrane imaju svoja prava i dužnosti te da braneći svoju nacionalnu neovisnost i integritet „istovremeno štite jugoslovensku zajednicu u celini”. S organiziranjem omladine u pripremanju općenarodne obrane, što je uključivalo i stvaranje posebnih omladinskih sastava, trebalo je odmah početi. Zbog obima poslova zaključeno je da je nužno razdvojiti pričuvne oficire i podoficire od bivših boraca, odnosno razdvojiti SUBNOR i Savez rezervnih vojnih starješina, i dati im precizne zadatke. ${ }^{18}$

Naglašena je odlučnost odupiranja bilo čijoj agresiji s temeljnim osloncem na svoje snage. „U slučaju invazije svaka fabrika, naselje i svaki grad moraju postati tvrđava sposobna da se suprotstavi agresoru i onda kada on okupira naselje ili grad." ${ }^{19} \mathrm{~S}$ tom je točkom inicirana obrana svake stope zemlje i segment koncepcije općenarodne obrane koji je u kasnijim razradama zvan nenaoružanim otporom agresiji, a čija je svrha bila vezivanje što većih snaga napadača za okupirana područja. Sustav općenarodne obrane trebao je postati neodvojivi dio cjelokupnoga društveno-političkog i društveno-ekonomskog sustava. Evakuacije stanovništva iz gradova smatrane su suvišnim jer bi prouzročile veće ljudske žrtve, a ne bi dale željene rezultate. Evakuirati se

15 Društveno-političke organizacije bile su: Savez komunista Jugoslavije, Savez sindikata Jugoslavije, Socijalistički savez radnog naroda Jugoslavije, Savez socijalističke omladine Jugoslavije, Savez udruženja boraca narodnooslobodilačkog rata (SUBNOR) i Savez rezervnih vojnih starješina Jugoslavije. Društveno-političke zajednice bile su: federacija, republike, autonomne pokrajine, regionalne zajednice općina, gradske zajednice i općine.

16 HR-HDA-1220-CK SKH, D-SP-531: PCKSKJ, Zaključci proširenog Biroa PCKSKJ, str. pov. br. 02-20/2 od 5. 9. 1968.

17 HR-HDA-1220-CK SKH, D-SP-531: CKSKJ, Informacija o zajedničkoj sednici, str. pov. br. 03-14/1 od 6. 9. 1968.

18 HR-HDA-1220-CK SKH, D-SP-531: PCKSKJ, Zaključci proširenog Biroa PCKSKJ, str. pov. br. 02-20/2 od 5. 9. 1968.

19 Isto. 
moglo samo djecu, bolesne i ranjene osobe te neke tvorničke pogone i institucije za čiji je rad uvjet veće sigurnosti bio nužan. Za ostali, veći dio društva u uvjetima općenarodne obrane tražena je razrada načina osiguranja ratne proizvodnje i opskrbe. U svezi s tim naglašena je potreba učinkovitoga financiranja obrane na svim razinama društva. Naglašena je i nužnost osiguranja i razmještaja oružja, opreme i drugih sredstava za vođenje „svenarodnog odbrambenog rata”. Sugerirano je da se u mjeri koja je moguća sredstva za vođenje rata približe korisnicima da bi se u slučaju rata u što kraćem roku spojili ljudi i naoružanje. ${ }^{20} \mathrm{Na}$ sjednici održanoj 2. rujna naglašeno je da treba „strogo voditi računa kome se daje naoružanje i kako se ono čuva”. ${ }^{21}$

Državni sekretarijat za narodnu obranu, Generalštab JNA i sva druga nadležna tijela i komande JNA zaduženi su da odmah pristupe razradi sustava općenarodne obrane i „njegovoj neposrednoj primeni u svakodnevnoj aktivnosti jedinica naše narodne armije”. Jugoslavenska narodna armija zadužena je za pružanje izravne stručne, tehničke i kadrovske pomoći u pripremanju općenarodne obrane u radnim organizacijama, komunama i drugim društveno-političkim zajednicama. Naglašena je i nužnost izrade normativnih dokumenata, prvenstveno zakona o narodnoj obrani. Potenciran je i sigurnosni aspekt općenarodne obrane i nužnost svih čimbenika sustava da povećaju svoju budnost. ${ }^{22}$ Taj je zahtjev bio najava praktičnoga i teorijskoga uobličavanja zaštitne komponente koja je kasnije spojena s koncepcijom općenarodne obrane. Na sjednici Predsjedništva i Izvršnoga komiteta CK SKJ 2. rujna rečeno je da paralelno s pripremama zemlje za obranu od vanjskoga neprijatelja treba poduzeti i mjere za jačanje sustava unutarnje sigurnosti.

„U tu svrhu jačati i pomagati rad organa državne i javne bezbednosti i preduzeti potrebne mere da se onemogući delovanje neprijatelja u ovoj situaciji. [Savezno] Izvršno veće će odmah formirati komisiju od političkih ljudi za rukovođenje, nadzor i pomoć u operativnom radu organa državne i javne bezbednosti. Kasnije će ona biti zakonski legalizovana u Skupštini. I u republikama treba odmah formirati takve komisije ukoliko već ne postoje. Treba odmah predvideti i čitav niz preventivnih mera na planu unutrašnje bezbednosti." ${ }^{23}$

Zadnja točka zaključaka bila je obveza propagiranja, tj. sustavnoga objašnjavanja „radnim ljudima i građanima osnovnih principa koncepta opštenarodne odbrane". ${ }^{24}$ Značenje obrane za Partiju pokazuje i odluka sa sjednice proširenoga Biroa od 27. rujna 1968. da se osnuje posebna komisija CK SKJ za

20 Isto.

21 HR-HDA-1220-CK SKH, D-SP-531: CKSKJ, Informacija o zajedničkoj sednici, str. pov. br. 03-14/1 od 6. 9. 1968.

22 HR-HDA-1220-CK SKH, D-SP-531: PCKSKJ, Zaključci proširenog Biroa PCKSKJ, str. pov. br. $02-20 / 2$ od 5. 9. 1968.

23 HR-HDA-1220-CK SKH, D-SP-531: CKSKJ, Informacija o zajedničkoj sednici, str. pov. br. $03-14 / 1$ od 6. 9. 1968.

24 HR-HDA-1220-CK SKH, D-SP-531: PCKSKJ, Zaključci proširenog Biroa PCKSKJ, str. pov. br. $02-20 / 2$ od 5. 9. 1968. 
pitanja općenarodne obrane. ${ }^{25}$ Takve komisije osnovane su i pri republičkim i pokrajinskim savezima komunista.

Odmah nakon invazije na Čehoslovačku, u skladu s prvim partijskim napucima, u kolovozu 1968. Izvršni komitet CK Saveza komunista Hrvatske (SKH) „održao [je] više sjednica i radnih dogovora na kojima su razmatrani neki konkretni zadaci u vezi s događajima izazvanim okupacijom" Čehoslovačke. ${ }^{26}$ Dogovoreno je da se pri Predsjedništvu i Izvršnom komitetu CK SKH „formira neka vrsta vojne komisije, koja bi mogla u slučaju potrebe da preraste u Glavni štab”. ${ }^{27}$ U Zagrebu je 3. rujna 1968. održana sjednica republičkoga Savjeta narodne obrane na kojoj je partijsko, republičko i rukovodstvo JNA u SRH informirano o sjednici na Brijunima održanoj prethodnoga dana i odluci da počne provedba koncepcije općenarodnoga obrambenog rata. Rečeno je da provedba „koncepcije općenarodnog obrambenog rata pretpostavlja odlučan oružani otpor cjelokupnog naroda, a ne samo Armije”, te da je jedina mogućnost uspješnoga otpora da se „svugdje i na svakom mjestu od samog početka agresije suprotstavi svim sredstvima oružani narod”. Naglašeno je da civilni sektor u mogućem ratu treba imati mnogo aktivniju ulogu,

„[... [što u pripremama traži određenu preorijentaciju na stvaranje organizacionih formi za aktivnu oružanu borbu, a ne pasivnu zaštitu, kao što je to u dosadašnjim planovima priprema predviđeno. [...] Koncepcija općenarodnog obrambenog rata mora biti realizirana kroz niz organizacionih formi - teritorijalnih, omladinskih, radničkih i drugih oružanih jedinica civilnog sektora, čime će se osigurati da zemlja i svaki njen grad i naselja postane bastion otpora agresoru" ${ }^{28}$

$S$ tom je sjednicom počela provedba koncepcije općenarodne obrane $u$ Hrvatskoj. Slično je vjerojatno bilo i u ostalim republikama. Doneseni zaključci dostavljeni su preko partijskih kanala do razine općinskih komiteta, ali i svih općinskih savjeta narodne obrane, republičkih tijela, rukovodstava društveno-političkih organizacija, komandi armija i vojnoteritorijalnih tijela. U njima je traženo da se što prije stvore uvjeti za preuzimanje naoružanja teritorijalnih četa JNA koje su stavljene u nadležnosti skupština općina. Naoružavanju je dana velika pozornost, s tim da je u tom trenutku prioritet bio na opremanju dopunske milicije, težišno one u najugroženijim područjima. U zaključcima se nastojalo dati smjernice za rad u svim segmentima života, uključujući i postupanje s arhivskim gradivom i zaštitom spomeničke baštine. U cjelokupnu aktivnost na organiziranju općenarodne obrane uključivale

25 KLASIĆ, Jugoslavija i svijet 1968., 417-418.

26 HR-HDA-1220-CK SKH, D-P-4513: Zapisnik sa sastanka Izvršnog komiteta CK SKH, održanog 25. 8. 1968.

27 HR-SVA-RSNO, Zaključci sa sastanka Sekretarijata Savjeta narodne obrane Sabora SRH održanog 26. 8. 1968.

28 HR-SVA-RSNO, sjednica SNO SRH od 12. 11. 1968.: Zapisnik sa sjednice SNO SRH od 3. 9.1968 . 
su se postupno i druge društveno-političke i društvene organizacije, posebice Socijalistički savez radnog naroda, Savez socijalističke omladine, SUBNOR i Savez sindikata. ${ }^{29}$

Postupno, organizacijskim i kadrovskim osposobljavanjem tijela narodne obrane i sve većim uključivanjem svih drugih društvenih činilaca u realizaciju koncepcije, prestala je potreba da organizacije SKJ i dalje obavljaju operativne funkcije na organiziranju općenarodne obrane. Rezultat rada SKJ bilo je stvaranje veoma široke mreže državnih i društvenih tijela i institucija koje su se neposredno bavile organiziranjem društva za obranu. Uz postojeće savjete narodne obrane skupština općina, koji su se dotad savjetodavno bavili obrambenom sferom, problematikom općenarodne obrane bavile su se i posebne komisije u organizacijama i forumima Saveza komunista. Komisije za općenarodnu obranu osnovane su u gotovo svim radnim organizacijama i pri svim forumima društveno-političkih i mnogih društvenih i radnih organizacija i bile su odlučujuće u poticanju idejne, propagandne i organizacijske aktivnosti za provedbu koncepcije. ${ }^{30}$ U Hrvatskoj su vrlo brzo uočili da je u domeni obrane previše specijaliziranih tijela „čije se nadležnosti uslijed toga što nisu dovoljno precizirane međusobno isprepleću i što pojava tako širokog fronta specijaliziranih organa stvara objektivno u pojedinim sredinama teškoće u bržem i jačem direktnom uključivanju organa samoupravljanja i svih društvenih faktora u poslove općenarodne obrane". ${ }^{31}$

Ništa manje agilna od Partije nije bila ni JNA. Dobar dio promjena u njezinu preustroju realiziran je 1967. i dijelom 1968., a invazija na Čehoslovač$\mathrm{ku}$ ih je obesmislila. U rujnu se radilo na novim planovima i rješenjima, a u listopadu su počele velike promjene koje su do kraja 1968. znatno izmijenile organizaciju JNA. Postojeće četiri armijske oblasti preimenovane su u armije, pa se na kraju godine Kopnena vojska sastojala od šest armija: 1. sa sjedištem u Beogradu i zonom odgovornosti u središnjoj Srbiji i Vojvodini, 2. sa sjedištem u Nišu i zonom u jugoistočnoj Srbiji i Kosovu, 3. sa sjedištem u Skopju i zonom odgovornosti u Makedoniji, 5. sa sjedištem u Zagrebu i zonom u sjeverozapadnoj Hrvatskoj, dijelu Istre, Lici, na Banovini i Kordunu te u dijelu zapadne Bosne, 7. sa sjedištem u Sarajevu i zonom u Bosni i Hercegovini i Slavoniji te 9. sa sjedištem u Ljubljani i zonom u Sloveniji. Snage u Crnoj Gori organizirane su u Vojno područje Titograd sa sjedištem u Titogradu. Sa sjedištem u Splitu i zonom na moru, u priobalju, sjevernoj i srednjoj Dalmaciji osnovana je Vojnopomorska oblast kao spoj kopnene i pomorske komponente. Dio novih operativnih i operativno-strategijskih grupacija imao je granice

29 HR-HDA-1220-CK SKH, Komisija za ONO i DSZ: Izvršni komitet CKSKH, Zaključci Savjeta narodne obrane, str. pov. „R”, br. 43 od 13. 9. 1968.; HR-SVA-RSNO, RSNO SRH, ožujak 1969., Izvještaj o provođenju obrambenih priprema na teritoriji SRH u 1968. g.

30 HR-HDA-1220-CK SKH, Komisija CKSKH za ONO i DSZ, kut. 9: Komisija PSKJ za ONO, januar 1971., Informacija o stanju i aktuelnim idejno-političkim problemima organizovanja opštenarodne odbrane, 2-3.

31 HR-SVA-RSNO, RSNO SRH, aprila 1970., Izvještaj o stanju obrambenih priprema i radu na realizaciji koncepcije općenarodne obrane u 1969. godini, 3. 
koje su se poklapale s republičkima, pa se shodno tome u literaturi može naći i tvrdnja o republičkom ustroju. Međutim, to se odnosi samo na tri republike. ${ }^{32}$

Na sjednici Savjeta narodne obrane Jugoslavije ${ }^{33}$ 27. listopada 1969. razmatralo se što je učinjeno na provedbi koncepcije općenarodne obrane i zadataka postavljenih na sjednici toga tijela godinu dana prije. Zaključeno je da je koncepciju prihvatilo „celo naše društvo kao jedinu moguću alternativu uspešnog suprotstavljanja agresoru, i ona, kao integralni deo našeg samoupravnog sistema, predstavlja značajan faktor u daljem razvoju naše zemlje i bezbednosti" ${ }^{34}$

U veljači 1969. donesen je Zakon o narodnoj obrani, koji je bio osnova za razvoj sustava obrane premda se na problematici ubrzano radilo i prije njegova donošenja. Zakon je posebice važan za upravne segmente izvan federacije jer je dotad obrana bila njezina domena i svodila se na JNA i njezino servisiranje od strane republika. Najveća novina bilo je osnivanje Teritorijalne obrane, čime se prešlo na ravnopravne dvokomponentne oružane snage, što je bio jedinstven slučaj u svijetu. U Zakonu je Teritorijalna obrana definirana kao oružani postroj kojim se

„[...] pokriva cela teritorija zemlje oružanim formacijama sposobnim da vode oružanu borbu i spremnim da se u svakom trenutku i u svim uslovima uspešno suprotstave agresoru. Jedinice teritorijalne odbrane dejstvuju samostalno ili sa jedinicama Jugoslavenske narodne armije. U određenim uslovima rata one mogu postati osnovni nosilac oružane borbe". ${ }^{35}$

Teritorijalnu obranu organizirale su općine, pokrajine i republike po jedinstvenim načelima na teritoriju cijele zemlje, a u ratu je u njezinu sastavu bila i milicija. ${ }^{36}$ Ustrojavanje po republikama različito se odvijalo. ${ }^{37} \mathrm{U}$ Hrvatskoj je njezin ustroj počeo nakon što su iz vojnoteritorijalnih tijela JNA preuzete teritorijalne čete. Te su postrojbe podređene skupštinama općina, a na inicijativu SKH i Saveza omladine osnovane su omladinske i radne jedinice.

\footnotetext{
32 MARIJAN, Slom Titove armije, 47-49.

33 U Savjetu su bili najistaknutiji funkcionari SFRJ, s tim da se sastav često mijenjao. Čelnik je bio predsjednik Republike i vrhovni komandant Oružanih snaga SFRJ, a po dužnosti su članovi bili predsjednik Savezne skupštine, predsjednik Saveznoga izvršnog vijeća, predsjednici republičkih izvršnih vijeća, državni sekretar za narodnu obranu i njegovi pomoćnici za civilni sektor i pozadinu te načelnik Generalštaba JNA. U srpnju 1969. Savjet je imao 30 članova. „Odluka o razrešenju i imenovanju članova Saveta narodne odbrane Jugoslavije od 16. 7. 1969.", Službeni list SFRJ (Beograd), br. 31, 24. 7. 1969. U rujnu 1971. Savjet je preimenovan u Savjet za poslove narodne obrane Predsjedništva SFRJ i koji je tada imao 33 člana. „Odluka o imenovanju članova Saveta za poslove narodne odbrane od 16. 9. 1971.”, Službeni list SFRJ, br. 48, 28. 10. 1971.; „Zakon o Savetu za poslove narodne odbrane Predsjedništva SFRJ od 31. 1. 1973.", Službeni list SFRJ, br. 6, 8. 2. 1973.

34 HR-SVA-RSNO, sp. br. 01-130/1970: Zaključci sa sednice Saveta narodne odbrane Jugoslavije održane 27. oktobra 1969. godine.

35 „Zakon o narodnoj odbrani”, Službeni list SFRJ, br. 8, 19. 2. 1969., uvodna načela III.

36 Isto, čl. 12. i 14.

37 ŽIVKOVIĆ, Razvoj oružanih snaga SFRJ 1945-1985. Teritorijalna odbrana.
} 
Iz pričuva JNA stavljen je na raspolaganje kontingent naoružanja sa streljivom, a nešto naoružanja i opreme nabavile su društveno-političke zajednice i radne organizacije. Do kraja 1968. nekoliko desetaka tisuća ljudi u Teritorijalnoj obrani navodno je bilo spremno za borbu, a do 1. ožujka 1969. osnovano je 59 općinskih štabova i Glavni štab SRH, kao i oko 1490 omladinskih jedinica, u kojima je bilo 135590 omladinaca i omladinki. Do kraja 1968. osnovana je 501 radnička jedinica, u koje je uključeno 33945 radnika. Temeljni problem pri ustroju Teritorijalne obrane bilo je oružje: bilo ga je malo, a problematičan je bio i njegov smještaj. Krajem 1968. oružja je bilo tek toliko da se moglo konstatirati da zadovoljava najnužnije potrebe osiguranja teritorija i naoružavanje samo jednoga dijela osnovanih postrojbi Teritorijalne obrane. Usto dio oružja dobivenog iz pričuve JNA nije bio potpuno ispravan. ${ }^{38}$

Osnivanjem Teritorijalne obrane u republikama i pokrajinama otvoreno je i pitanje nacionalnih armija. U razgovoru koji je redakcija časopisa Saveznoga sekretarijata za narodnu obranu Vojno delo organizirala početkom 1969. o koncepciji općenarodne obrane dio sugovornika dotaknuo se i dileme vodi li organizacija Teritorijalne obrane prema stvaranju nacionalnih armija. Poslanik u Saveznoj skupštini, a ubrzo i predsjednik Saveznoga izvršnog vijeća, Mitja Ribičič smatrao je da nema temelja za takve tvrdnje u socijalističkom samoupravnom društvu koje ima svoju operativnu armiju (JNA) i državi u kojoj nema čistih nacionalnih granica. To je bio prilaz s klasnoga prema nacionalnom, gdje je klasa osnovni subjekt, a „nacija onaj faktor koji preko svojih republičkih organa, u svojoj užoj društvenoj zajednici preko svojih samoupravnih organizama, kreira koncepciju opštenarodne odbrane i istovremeno stvara sredstva za očuvanje svoje nacionalne suverenosti i nezavisnosti”. Dodatni mu je argument bio da u problematičnome međunarodnom okruženju i blokovskom antagonizmu „integritet Jugoslavije predstavlja jedinu sigurnost za sve narode i narodnosti naše zemlje”. Doima se da je Ribičič imao ulogu poslati umirujuću poruku JNA da širenje poslova obrane na druge subjekte „ne znači razbijanje jedinstva sistema, već njegovu izgradnju na novim, višim samoupravnim osnovama”, te da je koncepcija općenarodne obrane „element integracije našeg društva". ${ }^{39}$

Uz Teritorijalnu obranu, velika je pozornost dana i civilnoj zaštiti, koja je od 1963. bila resor u Saveznom sekretarijatu za narodnu obranu. ${ }^{40} \mathrm{O}$ njoj su se od jeseni 1968. počele skrbiti i republike i pokrajine. Iz primjera Hrvatske tijekom 1968. i 1969. vidljiv je niz poteškoća oko njezina organiziranja. ${ }^{41}$ Republički sekretarijat za narodnu obranu SRH sačinio je potkraj studenoga 1968. naputak za osnivanje općinskih komandi Teritorijalne obrane i civilne zašti-

38 HR-SVA-RSNO, RSNO SRH, ožujak 1969., Izvještaj o provođenju obrambenih priprema na teritoriji SRH u 1968. g.

39 RIBIČIČ, „O koncepciji opštenarodne odbrane”, 6-8.

40 MIŠKOVIĆ, MANDIĆ, Civilna zaštita u SFRJ, 25.

41 HR-SVA-RSNO, RSNO SRH, ožujak 1969., Izvještaj o provođenju obrambenih priprema na teritoriji SRH u 1968. g., 27. 
te. ${ }^{42}$ Do kraja godine u općinama su osnovane postrojbe $u$ jačini od združene čete do združenoga odreda, kao i postrojbe u oko 800 radnih organizacija. Služba izviđanja, obavještavanja i uzbunjivanja kao dio civilne zaštite sporo se organizirala, uglavnom zbog nedostatka opreme, koja je bila preskupa za općine koje su ju trebale financirati. U svezi s mjerama zaštite i spašavanja pojačan je rad, prvenstveno oko problema opskrbe vodom i adaptacije postojećih i izgradnje novih skloništa. Na teritoriju SRH tada je bilo 1128 raznih skloništa s kapacitetom za 177600 osoba, koja su bila uporabljiva samo za zaštitu od klasičnih napadnih sredstava. U većim je gradovima počelo preispitivanje podrumskih prostorija u stambenim i drugim zgradama koje bi se nakon minimalnih adaptacija mogle koristiti kao sigurnija skloništa za građane. U sferi privrednih djelatnosti i društvenim službama također se radilo na pripremama za rat. Zbog invazije na Čehoslovačku Žitozajednica je po nalogu Savezne direkcije za rezerve premjestila 157971 t pšenice iz žitorodnoga područja SRH. Na dvadeset većih željezničkih čvorova osnovani su radnički odredi sa 2372 radnika, za koje je osigurano oružje i streljivo. Dio poduzeća za ceste osnovao je radničke odrede i pribavljao naoružanje za njih. ${ }^{43}$

U svezi s izobrazbom stanovništva za samozaštitu angažirani su koordinacijski odbori Socijalističkoga saveza za masovne pripreme stanovništva, narodna i radnička sveučilišta, centri narodne obrane, aktivi predavača, vojnih i drugih stručnih kadrova i organizacija. Republički sekretarijat za narodnu obranu SRH u zajednici s RTV-om Zagreb pripremio je ciklus TV emisija iz oblasti samozaštite koje su se počele prikazivati početkom 1969. godine. Krajem 1968. nakon dva desetljeća provođenja, reorganizirana je predvojnička izobrazba na temelju uočenih slabosti te su izrađeni novi orijentacijski programi za osnovne škole, škole II. stupnja, više škole i fakultete. Nastojao se povećati praktični dio izobrazbe u rukovanju oružjem i zaštitnom opremom. ${ }^{44}$ Izobrazba građana za obranu temeljitije je uređena Zakonom o narodnoj obrani iz veljače 1969. godine. Toj su obvezi podlijegali svi građani SFRJ u dobi od 16 do 65 godina ako su sposobni za pohađanje izobrazbe. Kad se izobrazba vodila u okviru nastavnoga programa u školama, podlijegali su joj i učenici mlađi od 16 godina. Izobrazba stanovništva organizirala se i provodila na tečajevima, seminarima, praktičnim vježbama i na druge prikladne načine. ${ }^{45}$ Kulminacija toga pristupa bila je uvođenje predmeta Osnovi općenarodne obrane SFRJ u visokoškolske ustanove ujesen 1974., predmeta Prva pomoć i zaštita u osnovne te predmeta Obrana i zaštita u srednje škole ujesen 1975. godine. ${ }^{46}$

42 HR-HDA-1220-CK SKH, Komisija CKSKH za ONO i DSZ, kut. 6: RSNO SRH, Uputstvo za organizaciju i formiranje općinskih komandi za rukovođenje TO i CZ, str. pov. br. 01-140/5-68 od 20. 11. 1968.

43 HR-SVA-RSNO, RSNO SRH, ožujak 1969., Izvještaj o provođenju obrambenih priprema na teritoriji SRH u 1968. g., 3, 16-22, 35-41.

44 Isto, 43-45.

45 „Zakon o narodnoj odbrani”, Službeni list SFRJ, br. 8, 19. 2. 1969., čl. 139.-142.

46 „Društveni dogovor o zajedničkim i jedinstvenim osnovama naučno-nastavnog rada iz oblasti opštenarodne odbrane na visokoškolskim ustanovama u SFRJ od 26. 4. 1974.” i „Do- 
$\mathrm{Na}$ 18. sjednici Predsjedništva SKJ 2. lipnja 1971. razmatrana je informacija Komisije za općenarodnu obranu o stanju i problemima provođenja koncepcije. Informacija je u kratkim crtama prezentirala postignuća, ali i probleme koji su se javljali. Ti su problemi izloženi u 12 točaka i pokazuju slabosti i otpore daljnjem podruštvljavanju koncepcije općenarodne obrane. Prvi je problem bilo sužavanje aktivnosti, što se moglo smatrati kampanjskim shvaćanjem da je opasnost od agresije prošla i da se ne treba žuriti u mjeri u kojoj je partijski i državni vrh očekivao. Dio tih problema bio je i odraz nerazumijevanja koncepcije na nižim razinama. No to je bio problem i na višim razinama jer ni sami vrhovi nisu bili načistu s tim što žele, a proces je otvarao niz neočekivanih problema, što nije neobično, nego posljedica ulaska u nepoznato područje koje je do 1968. bilo ekskluzivna sfera JNA, koja je uz ostalo štićena i rigoroznim mehanizmom vojne tajne. U skladu s tim na nekim se razinama javljala nedoumica o razmjerima upoznavanja predstavničkih i samoupravnih tijela s tom problematikom. Većih problema bilo je i oko rukovođenja domenom općenarodne obrane jer je do 1968. obrana bila u nadležnosti JNA, a po novom pristupu traženo je vrlo široko uključivanje društveno-političkih zajednica i društveno-političkih organizacija uz namjenski osnovana tijela, prvenstveno štabove Teritorijalne obrane. Problem se u SFRJ različito rješavao, a na nižim razinama, posebice općinskim, postavljalo se pitanje međusobnoga odnosa štabova Teritorijalne obrane i općinskih sekretarijata za narodnu obranu. Problema je bilo i na hijerarhijskoj razini oko toga kome su podređeni štabovi obrane, skupštinama općina ili tijelima državne uprave. U svezi s razvojem oružanih snaga nedoumica je bilo oko mjesta JNA i njezina otvaranja samoupravljanju, kao i zbog nekih nastojanja da Teritorijalna obrana bude njezina kopija. Naglašen je i problem nedostatka oružja i njegova nedijeljenja pripadnicima Teritorijalne obrane, što je negdje smatrano izrazom nepovjerenja. Bilo je primjedbi i na kadrovsku politiku u oružanim snagama, o problemu neravnomjernoga novačenja narodnosti u škole pričuvnih oficira, kao i problemu otvaranja visokih rukovodećih funkcija mlađim kadrovima. Time se ustvari otvaralo pitanje ustavnih prava naroda i narodnosti u općenarodnoj obrani, o čemu se dotad nije previše vodilo računa. Za pričuvne oficire ipak se inzistiralo da temeljni uvjet bude kriterij političke odanosti jer se smatralo da će se na taj način postići bolja klasna struktura starješinskoga kadra. Velik problem bilo je financiranje jer je koncepcija općenarodne obrane povećala ionako goleme izdatke za obranu, koji su dotad išli isključivo na uzdržavanje JNA. Ekonomske migracije vojno sposobnoga stanovništva također su bile problem jer je veliki broj pripadnika ratne armije bio na radu u inozemstvu i postavljalo se pitanje kako to uskladiti s koncepcijom općenarodne obrane i potrebama države u slučaju rata. Inače je problem sudionika u obrani bio kompliciran i zbog nejasnih ili nedovoljno razrađenih odnosa spram specijaliziranih organizacija na koje se moglo računati, poput primjerice izviđača

govor o jedinstvenim osnovama obučavanja učenika za opštenarodnu odbranu u osnovnim i srednjim školama SFRJ od 13. 2. 1975.", Službeni vojni list (Beograd), br. 20, 15. 9. 1975. 
i zrakoplovnoga saveza, prvenstveno one koje su okupljale omladinu, premda se tada nametalo i pitanje uloge žena u organiziranju općenarodne obrane. U svezi s masovnim pripremama stanovništva za obranu posebno je mjesto imala nastava općenarodne obrane u školama i na fakultetima, kao i pitanje dotadašnje kvalitete predvojničke izobrazbe, za koju se smatralo da nije na nužnoj razini. Kritizirani su mediji, odnosno sredstva javnoga informiranja zbog neodgovarajućega praćenja te problematike, dijelom i zbog ustaljenoga gledišta da se radi o resoru koji je zaštićen vojnom tajnom, a dijelom zbog mišljenja da ta tema nije atraktivna širem čitateljstvu i ne podiže nakladu listova i časopisa. Smatralo se da se u razradi i znanstvenom i teorijskom radu nije učinilo dovoljno i da je vrlo malo stručnoga kadra (znanstvene institucije i znanstvenici) angažirano na toj problematici. ${ }^{47}$ Informacija je prihvaćena, a Predsjedništvo SKJ dalo je i konkretne zadatke za daljnji razvoj koncepcije, gdje se od komunista tražilo da prednjače i suprotstave se „tendencijama sputavanja ili ograničavanja samoupravnih prava radnih ljudi i građana na poslovima opštenarodne odbrane". ${ }^{48}$

Poseban problem razvoja općenarodne obrane bio je financijski. Jugoslavija je imala iznimno veliku mirnodopsku armiju za čije je uzdržavanje izdvajan golem novac. Prema podacima Instituta za strategijske studije iz Londona objavljenim u godišnjaku Military Balance, Jugoslavija je 1968. sa 5,7 posto bruto društvenoga proizvoda s Čehoslovačkom i Istočnom Njemačkom dijelila drugo mjesto u Europi zemalja koje najviše izdvajaju za vojsku. Taj se iznos povećao i čini se da je 1970. iznosio 5,9 posto bruto društvenoga proizvoda, što je bilo blizu brojke od 6,1 posto, koliko su u JNA smatrali dovoljnim za njezino financiranje. ${ }^{49} \mathrm{Ne}$ računajući JNA, u Hrvatskoj je prema nepotpunim podacima 1969. za općenarodnu obranu izdvojeno 122.114.557 dinara (prema tečaju, 1 dolar tada je iznosio 12,50 dinara), a planirano je da se u petogodišnjem razdoblju 1971. - 1975. izdvaja oko 0,34 posto bruto društvenoga proizvoda. ${ }^{50}$

47 „Informacija o stanju i aktuelnim idejno-političkim problemima organizovanja opštenarodne odbrane", u: Osamnaesta sednica Predsedništva Saveza komunista Jugoslavije, 11-47.

48 „Zaključci Predsjedništva SKJ o aktuelnim idejnim i političkim pitanjima izgradnje i daljeg razvoja opštenarodne odbrane", u: Osamnaesta sednica Predsedništva Saveza komunista Jugoslavije, 5-10.

49 HR-SVA-RSNO, Republički zavod za planiranje SRH, Razvojni plan općenarodne obrane SRH za razdoblje 1971.-1975. g., str. pov. br. 15-1971, veljača 1972.; LJUBIČIĆ, Diskusija na 18. sjednici PCKSKJ 2. 6. 1971., 80-81.

50 HR-SVA-RSNO, RSNO SRH, april 1970., Izvještaj o stanju obrambenih priprema i radu na realizaciji koncepcije ONO u 1969. godini, 71-73; HR-SVA-RSNO, Republički zavod za planiranje SRH, Razvojni plan općenarodne obrane SRH za razdoblje 1971.-1975. g., str. pov. br. 15-1971, veljača 1972. 


\section{Teorijsko određenje koncepcije općenarodne obrane}

Istovremeno uz razradu i primjenu koncepcije općenarodne obrane radilo se na njezinu propagiranju i tumačenju u skladu sa zaključcima sa sjednice partijskoga vrha 3. rujna 1968. Jedan od prvih tiskanih priloga koji je objašnjavao novu koncepciju bio je govor generala armije Ivana Rukavine na seminaru Socijalističkoga saveza radnog naroda Hrvatske o pripremama stanovništva za općenarodnu obranu i zaštitu u Crikvenici 25. rujna 1968. On je govorio o razvoju koncepcije i iskustvima iz Drugoga svjetskog rata na temelju kojih je stvarana i kojom je tražena odgovarajuća organizacija da se

„[...] cjelokupno stanovništvo ne samo zaštiti nego i da se aktivno bori u obrani gradova, naselja i rajona u kojima živi u fazi kad neprijateljske snage do njih prodru, a kasnije da tu istu borbu nastavi u pozadini neprijateljskih snaga partizanskim načinom djelovanja. Mi de facto prvi put nastojimo ostvariti ideju da se u slučaju napada na našu zemlju agresoru suprotstavi čitav organizirani i naoružani narod". ${ }^{51}$

Skrenuo je pozornost na to da se na taj način i „civilni sektor” potpuno uključuje u obranu, što dotad nije bio slučaj jer je imao pasivnu ulogu i ponašao se u skladu s njom. Navodeći primjer Čehoslovačke, koju su Sovjeti i njihovi saveznici okupirali u roku od šest sati, Rukavina je naglasio da se takva sudbina može izbjeći samo pripremama i osposobljavanjem naoružanoga naroda za odlučnu borbu, što će biti opomena svakom potencijalnom agresoru da „dobro razmisli da li da se upusti u takvu dugotrajnu iscrpljujuću borbu, a ako do nje ipak dođe, onda nam se pružaju objektivne mogućnosti da je s uspjehom vodimo". ${ }^{2}$

Na Devetom kongresu SKJ u ožujku 1969. predsjednik SKJ Tito rekao je da je koncepcija općenarodne obrane jedina alternativa očuvanju slobode, neovisnosti i suvereniteta "naših naroda” i neometanoga razvoja socijalističkoga samoupravljanja.

„Ta koncepcija nije neko trenutno rješenje, izazvano aktuelnim međunarodnim događajima, već trajna orijentacija. Ona je, u stvari, nastala još 1941. godine, kada je KPJ povela naše narode u borbu protiv fašističkih okupatora $\mathrm{i}$ njihovih pomagača. Sa uvođenjem samoupravljanja u naš društveno-politički sistem i njegovim razvijanjem stvorene su kvalitativno nove mogućnosti za razradu i jačanje sistema opštenarodne odbrane. Podruštvljavanjem narodne odbrane, radni ljudi, radne i druge organizacije kao i društveno-političke zajednice postali su subjekti i aktivni činioci odbrane zemlje, što je njihova najviša dužnost i neotuđivo pravo." ${ }^{33}$

51 RUKAVINA, „O općenarodnoj obrani”, 5.

52 Isto, 5, 11.

53 BROZ TITO, „Aktuelni unutrašnji i međunarodni problem i uloga SKJ u socijalističkom sistemu samoupravljanja", 92. 
Nakon što je Tito koncepciju općenarodne obrane povezao sa 1941., to je postalo dominantno u njezinu tumačenju. Tito je potkraj 1969. u Ljubljani na proslavi 50-godišnjice Ljubljanskoga sveučilišta izjavio da neki u inozemstvu pogrešno prikazuju koncepciju općenarodne obrane kao nešto posve novo, što je on odbacio tvrdeći da su „tu koncepciju oformili i razvili još u našem narodnooslobodilačkom ratu, kada smo pozvali narod u borbu za odbranu svoje nezavisnosti i slobode”, i da njihova „današnja koncepcija opštenarodne odbrane nije ništa drugo nego dosljedna i odlučna primjena tih velikih iskustava iz narodnooslobodilačkog rata u našim sadašnjim uslovima" ${ }^{54} \mathrm{U}$ tom je govoru Tito rekao da je koncepcija

„[...] sastavni i neotuđivi dio našeg samoupravnog socijalističkog društva. Ona se sada razvija u uslovima mirne socijalističke izgradnje, u vrijeme kada smo ekonomski bogatiji, kada je samoupravljanje snažno razvilo društvenu svijest, odgovornost i spremnost da po svaku cijenu branimo revolucionarne tekovine i našeg narodnooslobodilačkog rata i samoupravnog socijalizma.

Samoupravni socijalistički društveni sistem omogućuje da udruženi proizvođači i građani organizuju odbrambene snage društva kao svoje sopstvene snage. To je, drugim riječima, podruštvljavanje odbrambenih poslova, angažovanje cjelokupnih odbrambenih snaga i potencijala društva, u čemu vidimo najsigurniju garanciju za obezbeđenje nezavisnosti i integriteta naše socijalističke zajednice". ${ }^{55}$

Govor u Ljubljani potkraj 1969. kasnije je s manjim varijacijama ili u izvodima bio nezaobilazan u razmatranju koncepcije, citiran ili davan kao prilog publikacijama o općenarodnoj obrani tijekom 70 -ih godina. ${ }^{56}$

U prosincu 1969. u razgovoru s članovima partijskoga vrha Hrvatske Tito je komentirao pogrešna shvaćanja koja su općenarodnu obranu svodila na mišljenje da je dovoljno „da se građanima daju puške”. Naglasio je da je općenarodna obrana mnogo šira, da "treba da djeluje u svakodnevnom životu”. Za njega je sastavni dio općenarodne obrane bilo „energično reagovanje naših građana, a posebno komunista", na sve pojave koje je Partija smatrala neprihvatljivim. ${ }^{57} \mathrm{U}$ konkretnom slučaju mislio je na pojave koje su u to vrijeme bile odraz popuštanja stege i koje se uobičajeno nazivaju liberalizacijom..$^{58}$

54 BROZ TITO, „Iskustva narodnooslobodilačke borbe i sistem opštenarodne odbrane”, 18.

55 Isto, 18.

56 U izvodima je primjerice tiskan u sljedećim publikacijama: Društvene osnove opštenarodne odbrane, 5-6; Osamnaesta sednica Predsedništva Saveza komunista Jugoslavije, 125-128; Općenarodna obrana, sigurnost $i$ društvena samozaštita - integralni dio socijalističkog samoupravnog sistema, 190-193; BROZ TITO, O opštenarodnoj odbrani, 96-98; BROZ TITO, Opštenarodna odbrana i društvena samozaštita, 534-546.

57 BROZ TITO, O opštenarodnoj odbrani, 52-53.

58 MIHALJEVIĆ, Komunizam i čovjek, 33-37. 
Od 13. do 15. svibnja 1970. u Beogradu je održan simpozij Teritorijalna odbrana u našem sistemu opštenarodne odbrane. ${ }^{59}$ Tito je sudionicima simpozija poslao pismo u kojem se kaže da je koncepcija općenarodne obrane

„[...] otvorila i produbila proces podruštvljavanja funkcije odbrane, u kome su svi subjekti našeg samoupravnog društva, od građanina do federacije, činioci koji odlučuju i sprovode u život sva bitna pitanja odbrane zemlje. Takva društvena funkcija općenarodne odbrane istovremeno predstavlja jaku kohezionu snagu našeg društva u ostvarivanju prava naroda i narodnosti naše zemlje u odbrani vlastitog samoupravnog razvoja, slobode u nezavisnosti socijalističke Jugoslavije, kao bratske zajednice ravnopravnih naroda i narodnosti” ${ }^{60}$

Radovi sa simpozija tiskani su iste godine u tri sveska internoga tipa, što znači da su bili namijenjeni strukturama obrane, ali ne i široj javnosti. Vjerojatno najzanimljiviji bio je rad pukovnika Miloša Prelevića o klasicima marksizma i naoružanome narodu. On je skrenuo pozornost na to da je vojna organizacija jugoslavenskoga socijalističkog društva do Brijunskoga plenuma bila jednostrana, a da su do kolovoza 1968. bile u optjecaju dvije krajnosti u tumačenju klasika - ultraradikalna i etatistička, pri čemu su ignorirana promišljanja o naoružanome narodu. Prema Preleviću, o potrebi organiziranja samoupravnoga socijalističkog društva prvi su put 1967. istupili Krste Crvenkovski na Plenumu CK SK Makedonije i Savka Dabčević-Kučar u intervjuu za Narodnu armiju potkraj iste godine. ${ }^{61}$

U zaključcima Prve konferencije SKJ, održane potkraj listopada 1970., ustvrđeno je da je koncepcija općenarodne obrane poticaj narodima i narodnostima da kroz nju afirmiraju „svoje nacionalne osobenosti i vrednosti, da ostvare svoj puni uticaj i odgovornost za jačanje zajedničke odbrane socijalističke Jugoslavije", što pokazuje intenciju da koncepcija bude integrativni čimbenik zemlje. U zaključcima se nalazi i stavka o nužnosti ugrađivanja društvene samozaštite u samoupravne odnose na svim razinama, počevši od radne organizacije i mjesne zajednice. „Na taj način ojačaće ukupna otpornost društvenog organizma prema svemu što neprijateljski deluje protiv socijalističkog razvoja. To će istovremeno upotpuniti opšte odbrambene snage zemlje."62

Iz navedenih primjera očito je da se koncepcija općenarodne obrane shvaćala mnogo šire od puke obrane teritorijalnoga integriteta SFRJ i da je tumačena kao učinkovit odgovor, ako ne na sve, onda na većinu problema koje je SKJ mogla imati pri upravljanju državom.

\footnotetext{
59 „Predgovor”, u: Simpozijum. Teritorijalna odbrana u našem sistemu opštenarodne odbrane, $\mathrm{V}$.

60 BROZ TITO, „Učesnicima simpozijuma 'Teritorijalna odbrana u našem sistemu opštenarodne odbrane"”, IX.

${ }_{61}$ PRELEVIĆ, „Klasici marksizma o organizovanju socijalističke društvene zajednice za oružanu borbu", 21.

62 „Izvod iz Zaključaka Prve konferencije SKJ o aktuelnoj političkoj situaciji i zadacima SKJ”, u: Osamnaesta sednica Predsedništva Saveza komunista Jugoslavije, 136-137.
} 


\section{Podruštvljavanje poslova sigurnosti i samozaštite}

Osamnaesta sjednica Predsjedništva SKJ održana je u lipnju 1971. u jeku „liberalizacije”, koja je neplanirano otišla u drugu krajnost i po Titovu mišljenju dovela u pitanje opstojnost Jugoslavije. Početkom prosinca 1971. na 21. sjednici Predsjedništva SKJ smijenjeno je rukovodstvo SKH, što je bio početak kraja „liberalizacije” i povratak čvrste ruke tijekom 1972., posebice ujesen iste godine nakon objave Pisma predsjednika SKJ i Izvršnoga biroa. ${ }^{63} \mathrm{U}$ međuvremenu, ljeto 1972. obilježila je potjera za ubačenom borbenom skupinom Hrvatskoga revolucionarnog bratstva Feniks u Bosni i Hercegovini i Hrvatskoj, čiji je cilj bio dizanje hrvatskoga naroda na ustanak. U knjizi o kriznim stanjima u SFRJ koju su 1989. napisali pukovnici JNA Dušan Vilić i Boško Todorović, inače istaknuti stručnjaci za problematiku ONO i DSZ, tvrdi se da je ubačena skupina donijela pozitivna iskustva u smislu da je definitivno

„[...] razbijena iluzija oko toga da jugoslovensku socijalističku samoupravnu zajednicu mogu samo ugroziti spoljne oružane snage, odnosno spoljna agresija. Posle ubacivanja i likvidacije navedene terorističke grupe ubrzano se prišlo, na najvišem nivou, kao i na nižim nivoima, procenama i analizama o mogućim opasnostima po bezbednost SFRJ i njenih delova izazvanih kontrarevolucionarnim delovanjem unutrašnjeg neprijatelja u sprezi sa inostranim faktorom". ${ }^{4}$

Iako su neki tumači koncepcije općenarodne obrane iz redova JNA prilično neuvjerljivo negirali da je skupina Feniks izazvala zaokret u doktrini unutarnje sigurnosti, priznaju da su „svakako njena pojava i iznenađenje koje je izazvala ubrzali mere i postupke oko usvajanja političkih, pravnih, doktrinarnih i organizacijskih dokumenata i mera organizovanja društva za njegovu odbranu od raznih oblika specijalnog rata". ${ }^{65}$

Već 21. srpnja 1972. slijedila je Direktiva predsjednika Republike i vrhovnoga zapovjednika Oružanih snaga SFRJ Josipa Broza Tita kojom je sustavu društvene sigurnosti naređeno da prevenira i u korijenu spriječi svaki pokušaj rušenja ustavnoga poretka ili ugrožavanja suvereniteta i neovisnosti SFRJ ${ }^{66}$ Nakon Direktive slijedio je još jedan obvezujući dokument. U spomenutoj knjizi pukovnika JNA o kriznim stanjima tvrdi se da je 1972. proces izgradnje novoga sustava ONO i DSZ počeo „odlukom donesenom na najvišem nivou državnog i političkog rukovođenja o neophodnosti preduzimanja svestranih priprema za odbranu države od svih oblika ugrožavanja, bilo spolja, ili

${ }^{63}$ RADELIĆ, Hrvatska u Jugoslaviji 1945. - 1991., 451-462; I. GOLDSTEIN, S. GOLDSTE-

IN, Tito, 705-719.

${ }_{64}$ TODOROVIĆ, VILIĆ, Vanredne prilike, 71.

65 Isto.

${ }^{66}$ Direktiva Predsednika Republike i Vrhovnog komandanta oružanih snaga SFRJ od 21.

7. 1972. (preslika dokumenta iz Arhiva Slovenije u posjedu autora). 
unutra”. ${ }^{67} \mathrm{Tu}$ odluku, odnosno zaključke o širem aspektu pitanja sigurnosti zemlje, donijelo je Predsjedništvo SFRJ 19. rujna 1972. godine. Jedna točka Zaključaka odnosila se i na društvenu samozaštitu:

„Društvenu samozaštitu, kao najširu osnovu na kojoj se ostvaruje sigurnost u našem samoupravnom socijalističkom društvu, treba brže razvijati i organiziranije postaviti. Normativno regulirati osnove jedinstvenog i usklađenog funkcioniranja svih službi sigurnosti, te prava i obaveze građana, radnih i drugih organizacija u ostvarivanju društvene samozaštite. Pri ovome treba pokrenuti i široku političku akciju zasnovanu na općoj podršci radnih ljudi u pravcu organiziranja i osposobljavanja društva na dugoročnijoj osnovi za efikasno suprotstavljanje svim nasrtajima na našu socijalističku zajednicu.

Sve društvene činioce treba, u ustavnim i zakonskim okvirima, činiti odgovornim za sigurnost zemlje, polazeći od toga da upravo organiziranost, rad i sigurnost znače suštinsku zaštitu samoupravnog socijalističkog društvenog uređenja i demokratskih prava i sloboda građana, a ne zavođenje režima 'čvrste ruke', kako to neprijatelj želi predstaviti, jer upravo njemu odgovara nered i neorganiziranost. Zbog toga su od odlučujućeg značenja i unutrašnja stabilnost, organiziranost na temelju samoupravnih odnosa utvrđenih Ustavom i stalna politička akcija." ${ }^{8}$

U siječnju 1973. na savjetovanju u Izvršnom birou Predsjedništva SKJ na temu borbe protiv „nacionalizma, neprijateljske aktivnosti, privrednog kriminaliteta i drugih devijacija u društvu" i provedbi stajališta iz Pisma predsjednika SKJ i Izvršnoga biroa bilo je govora i o društvenoj samozaštiti. U partijskom vrhu bilo je i bojazni od vraćanja na stanje prije Brijunskoga plenuma, očito zbog ponovnoga naglašavanja uloge službi sigurnosti u društvu. Inzistiralo se na daljnjem poticanju propagiranja društvene samozaštite kao izrazu izrastanja iz svijesti radničke klase i radnih ljudi i potrebi zaštite njihovih samoupravnih prava i interesa razvoja socijalističkih odnosa. U jačanju sustava sigurnosti i samozaštite smatrano je nužnim raščistiti sva otvorena pitanja mjesta i uloge pojedinih službi u sistemu i normativno odrediti njihove funkcije i nadležnosti, međusobne odnose, odgovornost i druga pitanja koja praksa nameće.

„Neophodno je da se u sistemu društvene bezbednosti i samozaštite ostvari takav spoj rada i odgovornosti svih organa samoupravljanja, predstavničkih tela, državnih organa i službi i ostalih političkih činilaca posebno Saveza komunista i društveno-političkih organizacija, kako bi ovi sinhronizovano i jedinstveno delovali u borbi protiv svih vrsta unutrašnjih i spoljnjih neprijatelja. U toj akciji zadaci svih tih institucija treba da su jasno razdeljeni i konkretno definisani u svakom konkretnom slučaju borbe." ${ }^{\prime 9}$

67 TODOROVIĆ, VILIĆ, Vanredne prilike, 72.

68 HR-HDA-1220-CK SKH, D-SP-681: Predsjedništvo SFRJ, Zaključci, str. pov. br. 122 od 19. 9. 1972.

${ }^{69}$ HR-HDA-1220-CK SKH, Predsjednik CKSKH - Političko-sigurnosna situacija, kut. 1: PCKSKJ, Informacija, str. pov. br. 2403-9/1-11 od 26. 2. 1973. 
Naglašeno je da su dotad osnovana koordinacijska tijela u republikama, konkretno Srbiji i Sloveniji, pokazala učinkovitost i da njihov primjer treba kritički analizirati u daljnjem radu. ${ }^{70}$

Na proširenoj sjednici Izvršnoga biroa Predsjedništva SKJ o aktualnim pitanjima jačanja sigurnosti i samozaštite održanoj 12. lipnja 1973. SKJ i druga društveno-politička i samoupravna tijela i organizacije obvezani su djelovati u smjeru još brže izgradnje društvene samozaštite kao najširega i samoupravnom socijalističkom društvu najadekvatnijega oblika organizacije sigurnosti da bi sigurnost zemlje postala briga i obveza cijeloga društva. Organizirane socijalističke snage na čelu sa Savezom komunista obvezane su na aktivan doprinos jačanju sigurnosti kroz stalnu obvezu s ciljem da to postane „patriotska dužnost radnih ljudi i građana. Treba se boriti za izgradnju takvog odnosa i svesti ljudi da suradnju, pružanje pomoći i podrške organima unutrašnjih poslova u borbi protiv unutrašnjeg i spoljnjeg neprijatelja i nosilaca drugih kriminalnih delatnosti prihvate kao svoju samoupravnu i građansku dužnost" ${ }^{71}$

Sustavniji rad na definiranju društvene samozaštite počeo je s Rezolucijom Skupštine SFRJ od 12. srpnja 1973. godine. Rezolucija je politički dokument koji je društvenu samozaštitu vidio na svim područjima ugrožavanja samoupravljanja čije je vrijednosti trebala štititi. Zaštita od prijetnji bila je u rasponu od gospodarskoga kriminala do ustavnoga poretka, odnosno zaštite tekovina revolucije, u čemu su svoje obveze imale sve društveno-političke razine, od mjesne zajednice do federacije, kao i društveno-političke organizacije na svim razinama organiziranja. ${ }^{72} \mathrm{U}$ Rezoluciji je rečeno da se polazi od ustavnih načela i društveno-političkih osnova da je samozaštita najširi temelj za organiziranje sigurnosti jugoslavenskoga samoupravnog društva; da je „društvena samozaštita izraz i funkcija samoupravnih socijalističkih odnosa; da se zaštita sloboda i prava radnih ljudi i građana te drugih društvenih vrijednosti najpotpunije ostvaruje usavršavanjem sistema samozaštite; da se sigurnost kao zajednički interes naroda i narodnosti, radnih ljudi i građana ostvaruje uz zajedničku odgovornost federacije, republika i autonomnih pokrajina; da je društvena samozaštita značajna osnova i za jačanje općenarodne obrane". ${ }^{73}$ Rečeno je da je razvijanje samozaštite, osobito na području zaštite ustavnoga poretka, bratstva i jedinstva, ravnopravnosti naroda i narodnosti kao i samoupravnih socijalističkih odnosa bitna pretpostavka i temelj za ostvarivanje i učinkovitost općenarodne obrane.

70 Isto.

71 HR-HDA-1220-CK SKH, D-SP-729: Zaključci Izvršnog biroa Predsjedništva SKJ [od 12. 6. 1973.] o aktuelnim pitanjima jačanja bezbednosti samozaštite samoupravnog društva.

72 „Rezolucija Skupštine SFRJ od 12. 7. 1973. o osnovama za ostvarivanje društvene samozaštite u sistemu samoupravljanja”, u: Društvena samozaštita. Politički dokumenti i savezni republički zakonski propisi, 7-18.

73 Isto, 7. 
„S obzirom na to da aktivnosti u organiziranju i provođenju društvene samozaštite i općenarodne obrane imaju jedinstven cilj, prijeko je potrebno osigurati potpunu usklađenost u provođenju tih aktivnosti."74

U referatu na Desetom kongresu SKJ, održanom potkraj svibnja 1974., Tito je rekao da dotadašnja izgradnja sustava ONO i DSZ „spada u najkrupnija ostvarenja našeg društvenog razvoja” i da je donošenjem Ustava i zakona koji ga prate u cjelini konstituiran „ovaj naš historijski gledano novi sistem odbrane. Nastao u periodu svenarodnog odbrambenog rata, u oružanom dijelu naše revolucije, on se razvijao zajedno sa samoupravnim socijalističkim sistemom kao jedan od njegovih bitnih činilaca". ${ }^{75}$ U kongresnoj Rezoluciji o zadacima SKJ u općenarodnoj obrani, sigurnosti i društvenoj samozaštiti rečeno je da su ONO i DSZ pravo i obveza „svih subjekata društva” i „još više moraju postati integralan dio samoupravnih društvenih odnosa i svakodnevnih funkcija društvenog i političkog sistema”, te da je podruštvljavanje poslova obrane i sigurnosti „revolucionarni proces i trajan interes radničke klase i narodnosti Jugoslavije”. ${ }^{76}$

U dijelu interne povijesti Oružanih snaga SFRJ na temu koncepcijskih pitanja tvrdi se da je Titov referat na Desetom kongresu SKJ bio prva javna elaboracija postojanja sustava ONO i DSZ. Autor toga dijela povijesti Oružanih snaga SFRJ, pukovnik Todorović, inače suautor knjige o kriznim stanjima, tvrdi i da je tada koncepcija ONO i DSZ konačno definirana. ${ }^{77}$ No do njezina oživotvorenja trebalo je proći još nekoliko godina. Nakon skupštinske Rezolucije društvena samozaštita dobila je mjesto u Ustavu SFRJ i ustavima republika i pokrajina, u kojima su utvrđene „društvene i političke osnove, predmet i sadržaj društvene samozaštite, kao i prava i odgovornost svih subjekata društva za njeno ostvarivanje”. To je omogućilo da se donesu republički i pokrajinski zakoni o osnovama društvene samozaštite, koja je „našla mjesto i u statutima općina, organizacija udruženog rada i mjesnih zajednica”. ${ }^{78} \mathrm{U}$ SRH je Zakon o osnovama društvene samozaštite donesen u veljači 1976., a prethodila mu je sjednica CK SKH o društvenoj samozaštiti u svibnju 1975. ${ }^{79}$

Na sjednici Saveznoga savjeta za zaštitu ustavnog poretka (prije: Savjet za državnu sigurnost Predsjedništva SFRJ) 5. veljače 1975. bilo je govora i o funkcioniranju sustava društvene samozaštite „kao osnovi na kojoj treba os-

74 Isto, 8.

75 BROZ TITO, „Borba za dalji razvoj socijalističkog samoupravljanja u našoj zemlji i uloga SKJ", 40.

76 „Rezolucija o zadacima SKJ u opštenarodnoj odbrani, bezbednosti i društvenoj samozaštiti”, u: Deseti kongres Saveza komunista Jugoslavije, 206-207.

77 TODOROVIĆ, „Koncepcija, doktrina i sistem opštenarodne odbrane u periodu od 1968. do 1985.", 306.

78 BAKARIĆ, „Aktuelna idejna i politička pitanja organiziranja i ostvarivanja društvene samozaštite", 38 .

79 Društvena samozaštita. Politički dokumenti i savezni i republički zakonski propisi, 66-74, 187-223. 
tvarivati bezbednost našeg samoupravnog društva”. Bilo je govora o nužnosti stvaranja odgovarajuće klime i razvijanju svijesti o potrebi poduzimanja mjera i akcija za zaštitu ustavnoga poretka i potenciranja uloge društvene samozaštite, odnosno njezinu sustavnom organiziranju na temelju prihvaćenih političkih stajališta i zakonskih odredbi. Službe unutarnjih poslova bile su angažirane na realiziranju društvene samozaštite, što je bilo neujednačeno po republikama i pokrajinama: negdje je bilo konkretnih aktivnosti, a drugdje je „postignut neznatan uspjeh”. Savjet je u zaključcima naglasio nužnost sustavnoga rada na organiziranju i bržem razvijanju društvene samozaštite „kao najšire osnove bezbednosti našeg samoupravnog socijalističkog društva”, u čemu „nisu postignuti zadovoljavajući rezultati”. Zaključeno je da društvenu samozaštitu „treba organizovati u svakoj organizaciji udruženog rada, mesnoj i društveno-političkoj zajednici, u kojoj će biti aktivan svaki radni čovek i građanin" ${ }^{80}$

Nedovoljnom razvoju i položaju društvene samozaštite u cijelosti je bila posvećena 13. sjednica Predsjedništva CK SKJ, održana 9. srpnja 1975., na kojoj su prihvaćena dva dokumenta: „Idejne i političke osnove organiziranja i ostvarivanja društvene samozaštite” i „Zaključci PCKSKJ o neposrednim zadacima SKJ u organiziranju i ostvarivanju društvene samozaštite". ${ }^{81} \mathrm{U}$ uvodnom izlaganju Vladimir Bakarić iznio je suštinu tih dvaju dokumenata i uopće sigurnosnu problematiku. Naravno, i on je krenuo s tezom da se $\mathrm{u}$ provedbi društvene samozaštite ne nalaze na početku, nego da su njezini elementi postojali u revolucionarnoj praksi Komunističke partije Jugoslavije.

„Naša sigurnost u narodnooslobodilačkom ratu i našoj socijalističkoj revoluciji je bila postavljena na najširoj osnovi i počivala je na samozaštitnom djelovanju svih politički organiziranih snaga narodnooslobodilačkog pokreta, prije svega, na visokoj svijesti i samozaštitnom ponašanju našega naroda koji je znao štititi osnovne tekovine revolucije, čuvati njene najveće tajne i bio spreman i na vlastito žrtvovanje radi zaštite svojih boraca, ranjenika, bolnica, skladišta, jedinica Narodnooslobodilačke vojske i svih drugih vrijednosti revolucije i narodnooslobodilačkog pokreta." ${ }^{2}$

Dotaknuo se Brijunskoga plenuma kao posljedice upozoravajućega primjera što se zbiva kad Partija zapostavi pitanje sigurnosti i zaštite. Zbog toga se Partija 1966. odlučila na potpunije uklapanje tijela i službi sigurnosti u samoupravni sustav, „odnosno na podruštvljavanje poslova sigurnosti i istakli potrebu da se Savez komunista redovito bavi ovim pitanjima”. Međutim, tek poslije 21. sjednice Predsjedništva SKJ i Pisma druga Tita i Izvršnog biroa „počeli smo se u Savezu komunista redovitije i sa više sistema baviti pitanji-

${ }^{80}$ Republički sekretarijat za unutrašnje poslove SRBiH, Stavovi i zaključci sa sjednice Saveznog savjeta za zaštitu ustavnog poretka, str. pov. br. 15-192/3 od 21. 4. 1975. Preslika dokumenta u posjedu autora. Stajališta su u formi okružnice distribuirana do razine sekretarijata za unutarnje poslove općine.

81 HR-HDA-1220-CK SKH, D-SP-1325: Zapisnik 13. sjednice PCKSKJ od 9. 7. 1975.

82 BAKARIĆ, „Aktuelna idejna i politička pitanja organiziranja i ostvarivanja društvene samozaštite", 36 . 
ma sigurnosti i njenim podruštvljavanjem" ${ }^{83}$ Bakarić je tumačio društvenu samozaštitu kao odraz podruštvljavanja poslova sigurnosti, što nije samo pravno-normativni akt nego i povijesni čin s dubokim revolucionarnim sadržajem.

„Njime se, u prvom redu, nastavlja i produbljuje, prije dvadeset i pet godina započeti, proces transformiranja funkcija naše socijalističke države u funkciju samoupravno organiziranih radnih ljudi i građana i dalje proširuju samoupravljačka prava našeg radnog čovjeka. Njegovo ostvarivanje podrazumijeva i suštinsko mijenjanje odnosa svih subjekata društva, počev od organa samoupravljanja i delegatskih skupština pa do specijaliziranih službi i organa zaštite, otkrivanja i gonjenja prema tako značajnim pitanjima društvenog života kao što su sigurnost i zaštita." ${ }^{34}$

Podruštvljena sigurnost prema takvu je pristupu bila pravo, ali i obveza svih organiziranih socijalističkih snaga, uključujući građane (no tu se očito tada radilo o obvezi), da u skladu s razvojem samoupravljanja jačaju aktivnu ulogu svih društvenih činilaca i razvijaju njihovu odgovornost za zaštitu ustavnoga poretka, samoupravnih i drugih prava radnih ljudi, sloboda čovjeka i građanina i društvene i osobne imovine. Takav angažman trebao je biti najjača brana svim prijetnjama samoupravnim pravima, pa i „birokratskoj samovolji, grupno-svojinskom ponašanju i nezakonitim postupcima pojedinca i grupa”. Naglasio je da društvena samozaštita

„[...] nije nekakav poseban društveni organizam ili organizacija u okviru ili izvan društveno-političkog sistema. Ona je, u stvari, samo redovna funkcija samog sistema, svih njegovih subjekata, čije su mjesto, uloga, odgovornosti i zadaci na ostvarivanju društvene samozaštite određeni mjestom, ulogom, pravima i odgovornostima koje inače imaju u društvu. [...]

Poslovi sigurnosti i zaštite prestaju, na taj način, biti isključivo poslovi specijaliziranih državnih i drugih organa i službi. Državni organi - sudovi, tužilaštva, organi unutrašnjih poslova, Služba društvenog knjigovodstva, inspekcije i drugi - sastavni su stručni dio društvene samozaštite čiji je zadatak da u ostvarivanju svojih zakonima utvrđenih funkcija najtješnje surađuju sa svim drugim nosiocima društvene samozaštite i u cjelini aktivno učestvuju u njenoj izgradnji”. 85

Bakarić je na kraju istaknuo da unutar sustava društvene samozaštite nema vodeće službe niti se planira stvaranje neke nove službe koja bi imala vodeću ili koordinacijsku ulogu, te da ni služba unutarnjih poslova ne može imati takvu ulogu. Koordinirati sve subjekte društvene samozaštite i društvene službe i tijela društveno-političkih zajednica mogu samo koordinacijska tijela društveno-političkih zajednica. ${ }^{86}$

83 Isto.

84 Isto, 39-40.

85 Isto, 40-41.

86 Isto, 43-44. 
U dokumentu „Idejne i političke osnove organiziranja i ostvarivanja društvene samozaštite” naglašeno je da „društvena samozaštita i općenarodna obrana, iako se različito ostvaruju, imaju isti osnovni cilj, istu društvenu i političku osnovu, međusobno se prožimaju i dopunjavaju i jedna na drugu oslanjaju". ${ }^{87}$

U neposrednim zadacima prihvaćenim na 13. sjednici CK SKJ komunisti su pozvani da „odlučno” prevladaju slabosti u razvoju društvene samozaštite, posebice one usko prakticističke i normativne nauštrb njezine izgradnje kao neposredne funkcije radnoga čovjeka i građanina, „kako bi u svim društvenim sredinama došla do punog izražaja klasna, idejna i socijalistička samoupravna društvena osnova samozaštite" ${ }^{88}$ Članovi SKJ i partijske transmisije: Socijalistički savez radnog naroda Jugoslavije, Savez sindikata Jugoslavije, Savez socijalističke omladine Jugoslavije i SUBNOR, pozvani su da što prije počnu s razradom mjera za organiziranje i ostvarivanje društvene samozaštite. U tome je trebalo informirati i mobilizirati sve radne ljude i građane i za to koristiti sve raspoložive resurse da bi se taj masovni posao realizirao. To je podrazumijevalo i njihovo uključivanje u proces donošenja pravno-normativnih akata $u$ oblasti društvene samozaštite, posebice u organizacijama udruženog rada i mjesnim zajednicama. U sredinama u kojima to nije učinjeno trebalo je osnovati koordinacijska tijela za društvenu samozaštitu sastavljena od predstavnika skupština i samoupravnih organa, društveno-političkih organizacija, organa radničke kontrole, sudova, tužilaštava, inspekcija, Službe društvenoga knjigovodstva i unutrašnje kontrole, organa unutarnjih poslova, carina, zapovjedništava postrojbi JNA i štabova Teritorijalne obrane. ${ }^{89}$

Na proširenoj sjednici Izvršnoga komiteta Predsjedništva CK SKJ 31. ožujka 1976. zaključeno je da je stanje sigurnosti u zemlji povoljno, ali da sistem samozaštite još uvijek ne funkcionira u svim sredinama na zadovoljavajući način.

„Posledice toga su štrajkovi, a u nekim organizacijama udruženog rada /pa i u vojnoj industriji/ slučajevi sabotaža, havarija, paljevina i sl. Ponegde su sami građani ukazivali na nosioce neprijateljskog i antisamoupravnog delovanja, ili su radnici otkrivali nosioce štetnih delatnosti. Međutim, sve su to još samo pojedinačni slučajevi, a morali bi se izboriti da građani shvate samozaštitu kao svoj svakodnevni zadatak i da takvog angažovanja bude sve više. U vezi sa ovim organizovanje samozaštite trebalo bi u republikama i pokrajinama svestranije i dublje razmotriti i preduzeti odgovarajuće mere radi njenog pospešavanja." ${ }^{90}$

87 „Idejne i političke osnove organiziranja i ostvarivanja društvene samozaštite”, u: Društvena samozaštita. Politički dokumenti i savezni i republički zakonski propisi, 52.

88 „Neposredni zadaci SKJ u organiziranju i ostvarivanju društvene samozaštite”, u: Društvena samozaštita. Politički dokumenti i savezni i republički zakonski propisi, 47.

89 Isto, 49-50.

90 HR-HDA-1220-CK SKH, D-SP-1455: Informacija sa 62. sjednice IK Predsjedništva CKSKJ od 31. 3. 1976. 
Za razliku od sustava općenarodne obrane, koja je ipak zaživjela, s društvenom samozaštitom bilo je problema i nerazumijevanja, u prvom redu zbog okolnosti da je sigurnosna funkcija do 1966. i Brijunskoga plenuma bila tabu-tema i zabran Uprave državne bezbjednosti. ${ }^{91}$ Zbog toga se o slabostima u provedbi društvene samozaštite raspravljalo na 27. sjednici Predsjedništva CK SKJ 2. ožujka 1977. U Informaciji pripremljenoj za sjednicu rečeno je da je nakon 13. sjednice poduzet veliki rad, da su se u idejno-političku akciju SKJ za organiziranje društvene samozaštite aktivno uključile sve društvene strukture. Na svim razinama osnovane su komisije, savjeti, odbori i druga radna tijela, organizirani razni oblici fizičke, tehničke i druge zaštite društvene imovine i objekata. Uz pohvale dobroj praksi, težište Informacije bilo je na slabostima u organiziranju društvene samozaštite. Te su slabosti u prvom redu bile odraz nerazumijevanja problematike, što je posebice bilo izraženo na nižim razinama organiziranja, uglavnom u dijelu općina, po mjesnim zajednicama i organizacijama udruženog rada. Negdje su osnovane odvojene komisije za ONO i DSZ, koje su izišle iz svojih okvira, tj. nadležnosti, i preuzimale ulogu svojih rukovodstava i organizacija, a njihova je uloga trebala biti pomoćna i savjetodavna rukovodstvima i organizacijama Saveza komunista. Negdje su se mnoga bitna pitanja rješavala u uskim rukovodećim krugovima, a ne pred radnim ljudima i kolektivima. Stupanj provedbe bio je različit po republikama i pokrajinama i pokazatelj je različitoga razumijevanja problematike, kao i različite razine primjenjivosti. U Sloveniji su bili najracionalniji jer su tada jedini imali zajednička tijela za ONO i DSZ. ${ }^{2}$ To je možda bio i najsuvisliji pristup jer je u prosincu 1976. Komisija CK SKH za ONO i DSZ na temelju analize djelovanja SKH na ostvarivanju koncepcije ONO i DSZ sačinila informaciju koja je naglasila neusklađenost u radu brojnih tijela na svim razinama, što se nepovoljno odrazilo na njihovu i opću učinkovitost. Drugi problem bilo je nedovoljno podruštvljavanje, pa se problematika u dijelu sustava svela na rad i odlučivanje rukovodilaca iz užega kruga i profesionalnih dužnosnika iz domene narodne obrane, koji su sami odlučivali o pitanjima s kojima će „izići pred organe samoupravljanja i radne ljude i građane". ${ }^{93}$

$\mathrm{U}$ raspravi na 27. sjednici Predsjedništva CK SKJ potvrđeno je da je društvena samozaštita „stalna komponenta i konstitutivni element društveno-političkog sistema i socijalističkih samoupravnih odnosa i da se u sve većoj meri ostvaruje kao pravo i dužnost svih članova našeg socijalističkog samoupravnog društva. Također je potvrđena potreba jačanja i povezivanja opštenarodne odbrane i društvene samozaštite, njihovog ravnomernijeg ra-

\footnotetext{
91 Usp. TODOROVIĆ, VILIĆ, Vanredne prilike, 74.

92 „Informacija o ostvarivanju zaključaka 13. sednice PCKSKJ i neki aktuelni zadaci na organizovanju i razvijanju društvene samozaštite", u: Dvadesetsedma sednica Predsedništva CKSKJ, 13-34.

93 HR-HDA-1220-CK SKH, D-SP-1549: Komisija CKSKH za ONO i DSZ, prosinac 1976. Informacija o izvršenoj analizi djelovanja organizacija SKH na ostvarivanju koncepcije ONO i DSZ.
} 
zvijanja i usklađivanja” ${ }^{94}$ U zaključcima sjednice konstatirano je da se društvena samozaštita razvija na crti „daljeg podruštvljavanja klasičnih funkcija države u oblasti bezbednosti. Ona je stalna komponenta i konstitutivni elemenat društveno-političkog sistema i socijalističkih samoupravnih odnosa i u značajnoj meri doprinosi demokratizaciji društvenih odnosa i društvenom razvitku uopće”. Predsjedništvo je istaknulo da „društvena samozaštita mora još potpunije da se integriše u celokupni društveno-politički i samoupravni život i da prožima idejno-političke, vaspitno-obrazovne, informativno-propagandne i sve druge aktivnosti našeg socijalističkog društva". ${ }^{95}$ Članstvu SKJ dani su zadaci za daljnju izgradnju sustava društvene samozaštite i od njih se tražila stalna idejno-politička aktivnost u njezinu daljnjem podruštvljavanju. Naglašeno je da uz postojeće treba razvijati i nove oblike organiziranja i osposobljavanja radnih ljudi i građana za zadatke društvene samozaštite u svim stanjima, uključujući i općenarodni otpor.

„Na taj način se, pored omasovljavanja sistema odbrane i zaštite, ostvaruje bolje međusobno povezivanje njihovih komponenti i čini dalji korak u razvoju koncepcije opštenarodne odbrane i u tim okvirima realizuje ideja o naoružanom narodu." 96

Od partijskih rukovodstava tražilo se da i dalje koordiniraju problematiku, s tim da je naglašena potreba da se u pokrajinama, republikama i federaciji u skladu s odredbama Ustava SFRJ, ustava republika i pokrajina, kao i zaključcima 13. sjednice Predsjedništva CK SKJ odrede odnosno konstituiraju tijela za usmjeravanje i koordinaciju društvene samozaštite i preciziraju njihova mjesta u postojećem ustavnom sustavu. Tijela za koordinaciju i usmjeravanje društvene samozaštite trebalo je osnovati u mjesnim zajednicama, organizacijama udruženog rada i općinama gdje još nisu postojala. Trebalo je osigurati i stalno unaprjeđivati funkcionalno povezivanje tijela za koordinaciju društvene samozaštite i općenarodne obrane na svim razinama, „uključujući i mogućnost jedinstvenih tela za ove potrebe u mesnim zajednicama, organizacijama udruženog rada i opštinama". ${ }^{97}$ To funkcionalno povezivanje nije bilo zamislivo bez institucionalnoga, odnosno personalnoga ugrađivanja Saveza komunista u sva tijela za usmjeravanje, koordinaciju i rukovođenje društvenom samozaštitom i općenarodnom obranom. ${ }^{98}$

94 HR-HDA-1220-CK SKH, D-SP-1592: Zapisnik sa 27. sjednice Predsjedništva CKSKJ održane 2. 3. 1977.

95 „Zaključci PCKSKJ o zadacima SK u razvoju društvene samozaštite”, u: Dvadesetsedma sednica Predsedništva CKSKJ, 7-8.

96 Isto, 9.

97 Isto, 10-11.

98 Isto, 11. 


\section{Osnivanje komiteta za ONO i DSZ}

Sa 27. sjednicom Predsjedništva CK SKJ i donesenim zaključcima najavljen je novi organizacijski oblik u obrambeno-zaštitnom sustavu. Stavovi sa sjednice bili su osnova za razmatranje oblasti ONO i DSZ na 11. kongresu SKJ. ${ }^{99} \mathrm{Na}$ kongresu održanom u lipnju 1978. izričito se naglašavalo da su ONO i DSZ jedinstveni obrambeno-zaštitni sustav čije je daljnje usavršavanje nužno. Predsjednik SKJ Tito istaknuo je da sustav ONO i DSZ

„[...] izgrađujemo kao integralni dio društvenog sistema socijalističkog samoupravljanja. U njegovoj osnovi su klasni interesi radničke klase i socijalistički samoupravni društveni odnosi. Opštenarodna odbrana i društvena samozaštita postali su sastavni dio samoupravnih prava, odgovornosti i obaveza radnih ljudi i građana i njihovih društveno-političkih zajednica i organizacija. [...] Poslovi opštenarodne odbrane i društvene samozaštite obavljaju se sve više, da tako kažem kroz rad i uz rad, postaju dakle, dio redovnih svakodnevnih aktivnosti i radnih zadataka. Radni ljudi i građani - samoupravljači - sami organizuju svoju odbranu i samozaštitu u radnim i društveno-političkim zajednicama, a samo neophodne zajedničke poslove prenose na društvene, za to specijalno organizovane institucije, kao što su Jugoslovenska narodna armija i službe bezbjednosti. Na taj način u praksi obezbeđujemo podruštvljavanje odbrambene funkcije, koja je u drugim društvenim sistemima otuđena od radnog čovjeka. To je praktično ostvarivanje marksističke koncepcije naoružanog naroda". ${ }^{100}$

U Rezoluciji o zadacima SKJ u razvoju i jačanju ONO i DSZ naglašena je potreba njihova većega povezivanja i stvaranja jedinstvenih rukovodećih tijela u svim društveno-političkim oblicima organiziranja u jedinstvenom sustavu, uz nezaobilaznu vodeću ulogu SKJ. ${ }^{101}$

Do kraja 1978. pripremljen je materijal s pregledom stajališta i smjernica za daljnji razvoj teorije i prakse ONO i DSZ kao jedinstvenoga i cjelovitoga obrambeno-samozaštitnog organiziranja. Materijal je 25. prosinca 1978. verificiran na zajedničkoj sjednici Savjeta za narodnu obranu Predsjedništva SFRJ i Saveznoga savjeta za zaštitu ustavnog poretka, kojom je predsjedao predsjednik Republike Tito. ${ }^{102}$ Naglašeno je da

99 TODOROVIĆ, VILIĆ, Vanredne prilike, 75.

100 BROZ TITO, „SKJ u borbi za dalji razvitak socijalističke, samoupravne i nesvrstane Jugoslavije", 44-45.

101 „Zadaci SKJ u razvoju i jačanju ONO i DSZ”, u: Jedanaesti kongres Saveza komunista Jugoslavije, 190-191.

102 Općenarodna odbrana i društvena samozaštita u funkciji zaštite ustavnog poretka i obrane nezavisnosti i teritorijalnog integriteta SFR Jugoslavije, službena tajna, povjerljivo, prosinac 1978. 
„[...] cjelokupno obrambeno i samozaštitno organiziranje društva, mjere i aktivnosti trebaju biti usmjereni u prvom redu na otklanjanju svih izvorišta ugrožavanja ustavnog poretka i sigurnosti zemlje i njihovo neutraliziranje, uključujući i onemogućavanje raznih aktivnosti koje vode mogućim kriznim situacijama. [...]

To su osnovni politički razlozi i okviri za daljnje razvijanje i usavršavanje općenarodne obrane i društvene samozaštite kao jedinstvenog samozaštitnog-obrambenog mehanizma u akciji. [...] Snagom svog ekonomskog i političkog samoupravnog sistema i dobre obrambene i samozaštitne organiziranosti društvo se najefikasnije brani od svega onoga što je sračunato na njegovo podrivanje, bilo da takve pokušaje odvraća ili ih djelotvorno onemogućava, uključujući i suprotstavljanje oružanoj agresiji”. ${ }^{103}$

Stoga se od ONO i DSZ kao oblika obrambenoga i zaštitnoga organiziranja očekivalo da bude učinkovita brana „svim mogućim nasrtajima na našu zemlju" da bi se spremno reagiralo na prijetnju bez većih reorganizacija i pomicanja. Zapravo se inzistiralo na preventivnoj ulozi snaga ONO i DSZ, a po potrebi i represijom. Tada, u prosincu 1978., smatralo se da općenarodna obrana u velikoj mjeri funkcionira po načelima na kojima je organizirana. ${ }^{104}$ Kao i u prijašnjim slučajevima, tj. doktrinarnim dokumentima, ponovljena je nužnost vodeće uloge i odgovornosti SKJ u obrani zemlje i zaštiti ustavnoga poretka. Sve pozicije i odlučivanje u sustavu ONO i DSZ morali su biti u rukama Partije, a rukovodstva Saveza komunista Jugoslavije te republika i pokrajina bila su dužna reagirati ako se u nekim sredinama, tijelima i organizacijama ne provodi politika Saveza komunista. ${ }^{105}$ Iako se tvrdilo da u sustavu odlučivanja, a u slučaju rukovođenja oružanim snagama, ne treba mijenjati ništa što nije propisano ustavnim i zakonskim rješenjima, nije isključena mogućnost da u kriznim stanjima neke instance odlučivanja budu spriječene ili onemogućene da obavljaju svoje ustavne nadležnosti, pa bi u takvim slučajevima Savez komunista morao biti nositelj uspostavljanja narušenoga sustava rukovodstva i jedinstva zemlje. Zbog toga je donesena odluka o osnivanju komiteta za ONO i DSZ u samoupravnim organizacijama i zajednicama (osnovne organizacije udruženog rada, radne organizacije i mjesne zajednice) i društveno-političkim zajednicama (općine, gradske ili regionalne zajednice, autonomne pokrajine i republike). ${ }^{106}$

„Ova tijela trebaju biti sastavljena od najpouzdanijih ljudi s najodgovornijih funkcija određene sredine ili nivoa. To trebaju biti autoritativna tijela po sastavu i dovoljno samostalna u procjenjivanju aktualne političke, sigurnosne i vojne situacije, u razmatranju svih bitnih pitanja ostvarivanja općenarodne obrane i društvene samozaštite i prema tome u poduzimanju odgovarajućih mjera. Po svom sastavu, sadržaju i metodi rada ova tijela trebaju imati karak-

\footnotetext{
${ }^{103}$ Isto, 3. Dijelovi teksta naglašeni su u izvorniku.

104 Isto, 3-4.

105 Isto, 5-8.

106 Isto, 19-20.
} 
ter operativno-političkog štaba rukovodstva i organizacija Saveza komunista i najviših izbornih organa društveno-političkih zajednica, odnosno organa upravljanja u samoupravnim organizacijama i zajednicama za oblast obrane i samozaštite. [...] Na čelu tog tijela trebaju biti predsjednici odnosno sekretari foruma ili organizacija Saveza komunista ili osoba koju predloži odgovarajući forum Saveza komunista." 107

Naglašeno je da osnivanje komiteta ne znači preuzimanje poslova bilo kojega postojećeg tijela upravljanja u matičnim sredinama, kao što ne bi trebali ograničavajuće utjecati na neke od postojećih pomoćnih, radnih, savjetodavnih i izvršnih tijela za ONO i DSZ. Komiteti su, tvrdilo se, trebali osigurati operativno-političko rukovođenje, usmjeravanje i ostvarivanje jedinstva ciljeva i zadataka ONO i DSZ „te pravovremeno i djelotvorno funkcioniranje jedinstvenog samozaštitnoobrambenog mehanizma u akciji”. Stavove, smjernice i odluke koje komiteti donesu nadležna tijela provodila bi na temelju postojećih mehanizama i u okviru prava, nadležnosti i odgovornosti. ${ }^{108}$

Osnivanje komiteta počelo je iduće, 1979. godine na svim razinama, od mjesne zajednice i osnovnih organizacija udruženog rada do republika i pokrajina. Na razini federacije nisu osnovani. Na kraju su 1980. u SRH bila 9242 komiteta sa 51054 članova, što je na primjeru jedne republike pokazatelj njihove masovnosti. ${ }^{109}$ Osnivanjem jedinstvenih komiteta za ONO i DSZ obrambeno-zaštitna problematika realno je združena u cjelinu, čime je, po svemu sudeći, kako-tako počelo i funkcioniranje te komplicirane koncepcije. Predviđano je da komiteti mogu uporabiti dio oružanih snaga u krajnje teškom stanju, pri čemu se podrazumijevao samo dio Teritorijalne obrane. ${ }^{110}$ To je inače bila neustavna mogućnost, no ni komiteti u vrijeme osnivanja nisu imali uporište u Ustavu ili zakonima. Zakonsko pokriće dobili su tek 1982. u Zakonu o općenarodnoj obrani, a potom u istovjetnim zakonima republika i pokrajina. ${ }^{111}$ Komiteti su osnivani u vrijeme kad nije bilo ozbiljne krize u Jugoslaviji, ali to ne treba zavarati - režim nije mogao funkcionirati bez proizvodnje „neprijatelja”, premda je nesumnjivo imao znatnu potporu dijela stanovništva.

107 Isto, 20.

108 Isto, 20-21.

109 HR-HDA-1220-CK SKH, KONO i DSZ SRH: Zbirni pregled osnovanih komiteta za općenarodnu obranu i društvenu samozaštitu u SR Hrvatskoj (stanje na dan 31. 12. 1980.); 17. sednica CK SKJ. Ostvarivanje stavova 11. kongresa SKJ o opštenarodnoj odbrani i društvenoj samozaštiti, 18-20.

110 HR-HDA-1616-PSRH, kut. 184: PSRH i PCKSKH, Smjernice za sprečavanje i eliminiranje eventualne krizne situacije u SRH, DT br. 12/1-1979 od 4. 4. 1979.

111 ATELJEVIĆ, PETKOVIĆ, Komiteti za opštenarodnu odbranu i društvenu samozaštitu. 


\section{Militarizam samoupravnoga socijalizma}

Bez obzira na razne tvrdnje s kraja 80-ih, sustav općenarodne obrane počeo se razvijati tek nakon invazije na Čehoslovačku u kolovozu 1968. godine. Nakon šoka Tito i Partija brzo su reagirali i potaknuli niz aktivnosti koje su s različitim intenzitetom trajale godinama. Rezultat je bio stvaranje koncepcije općenarodne obrane, a od sredine 70-ih i društvene samozaštite. Koncepcija je tumačena kao razrada klasika marksizma o naoružanome narodu i Titove genijalnosti tijekom Drugoga svjetskog rata. U rječniku socijalističkoga samoupravljanja govorilo se o podruštvljavanju poslova obrane i zaštite, što je bio eufemizam za militarizirano i policijsko društvo. Preko delegatskoga sustava, još jednoga neprovedivog izuma samoupravnoga socijalizma, podruštvljavanje obrane poprimilo je goleme razmjere. ${ }^{112} \mathrm{Na}$ najnižim razinama organiziranja, osnovnim organizacijama udruženog rada i mjesnim zajednicama, bilo je više od 85000 delegacija u dodiru s poslovima ONO i DSZ. Na višim partijskim i upravnim razinama takvih je delegacija bilo osjetno manje, no one ilustriraju podatak da je svaki trinaesti punoljetni Jugoslaven bio u nekoj od delegacija i u doticaju s poslovima obrane. ${ }^{113}$

Uvođenjem predvojničke obuke u škole potkraj 40-ih godina počinje militarizacija društva. ${ }^{114} \mathrm{Od}$ optužbi za militarizam, koje su postojale i prije 1968., iz JNA su se branili tvrdnjama da ga nema jer nema izoliranosti profesionalnoga armijskoga kadra i Armije, koja je čvrsto uključena u jedinstveni društveni mehanizam, tj. da "postoji političko jedinstvo armije i naroda". ${ }^{115}$ Savezni sekretar za narodnu obranu general Nikola Ljubičić također je negirao optužbe za militarizam.

„U vezi s tim treba istaći da je jasna razlika između podruštvljavanja odbrambenih poslova i militarizacije društva kojoj pribegavaju agresivne zemlje. Militarizacija je potčinjavanje društva državnom, političkom i vojnom vrhu radi vođenja agresivnog rata i ugnjetavanja radnih ljudi. Nasuprot tome, podrušttljavanje odbrambenih poslova kod nas je izraz jedinstva odbrambenih interesa i stvaralačke inicijative i aktivnosti najširih slojeva naroda, u smislu organizovanja i pripremanja za samoodbranu i samozaštitu od svih oblika ugrožavanja." ${ }^{116}$

Ljubičić je problem tumačio iz gledišta koje militarizam svodi na silu i utjecaj koji je prijetnja susjednim državama. Pritom je „zanemario” način na koji su komunisti 1945. preuzeli vlast i održavali se na njoj. „Zanemario” je i udio djelatnih vojnih osoba u strukturama društva, posebice od 1969. u Pred-

${ }_{112}$ O njemu u: GRDEŠIĆ et al., Delegatski sistem 1974-1984.

113 SIKIMIĆ, Odbrana u ustavnom sistemu SFRJ, 154-155.

114 KOREN, Politika povijesti u Jugoslaviji (1945-1960), 114.

115 DALJEVIĆ, Armija i njeno mesto u savremenom društvu, 50, 55.

116 LJUBIČIĆ, „Opštenarodna odbrana Jugoslavije”, 60-61. Ljubičićev članak nije konkretno datiran, no nastao je između 9. i 10. kongresa SKJ, tj. ožujka 1969. i svibnja 1974. godine. 
sjedništvu SKJ, odnosno od 1974. u Centralnom komitetu. U tom je smislu koncepcija ONO i DSZ bila još jedan od načina na koji je Partija štitila svoje „vlasništvo” u Jugoslaviji. To potvrđuje jedna interna ocjena iz 1989. da je koncepcija ONO i DSZ u „znatnoj meri bila i brana negativnim tendencijama u našem društvenom razvitku i značajan činilac političke kohezije zemlje, bratstva i jedinstva naših naroda i narodnosti i njihove ravnopravnosti". ${ }^{117}$ Sredinom 80-ih slovenski politolog Anton Bebler podruštvljavanje obrane nazvao je visokom „vojnizacijom”, što je bio inovativan eufemizam za militarizam. ${ }^{118}$

Iako su u JNA bespogovorno prihvatili koncepciju općenarodne obrane i stvaranje dvokomponentnih snaga, nakon Titove su je smrti u drugoj polovini 80-ih dobrim dijelom osporili i relativizirali. Potkraj 1990., u vrijeme raspada SFRJ, tadašnji savezni sekretar za narodnu obranu Veljko Kadijević izjavio je da je osnivanje Teritorijalne obrane krajem 60-ih i početkom 70-ih godina bila velika podvala koja je nakon sloma komunizma postala temelj ustrojavanja republičkih vojski. ${ }^{119}$ Njegov prethodnik na dužnosti saveznoga sekretara za narodnu obranu, admiral Branko Mamula, u svojim sjećanjima govori o susretu s Edvardom Kardeljem u proljeće 1978., koji mu je objašnjavao

„[...] vojnu filozofiju koju sam već imao prilike čuti od njega i Vladimira Bakarića početkom '70-ih na skupu visokih vojnih starješina u Domu JNA u Beogradu kada smo konstituirali sistem općenarodne odbrane. Nebulozan koncept koga tada većina, pa ni ja nije razumjela". ${ }^{120}$

\section{Zaključak}

Koncepcija općenarodne obrane i društvene samozaštite, kako se zvao jugoslavenski obrambeno-zaštitni sustav, velikim je dijelom bila improvizacija kojom je režim nastojao odgovoriti na izazove koji su ugrožavali njegov položaj. Koncepcija općenarodne obrane počela je nastajati u kolovozu 1968. nakon invazije zemalja Varšavskoga ugovora na Čehoslovačku. Na takvu iznenadnu agresiju, u kojoj je za samo nekoliko sati uspostavljen nadzor nad Čehoslovačkom, jugoslavenski komunisti smatrali su da učinkovito mogu odgovoriti samo angažmanom svih raspoloživih potencijala društva na temelju razmišljanja klasika marksizma o naoružanome narodu, ali i revolucionarnoga djelovanja Josipa Broza Tita u Drugom svjetskom ratu. Bila je to improvizacija koja je dodatno opteretila jugoslavensko društvo, povećala ionako goleme financijske izdatke za vojsku i ratne pripreme. Povećala je i stupanj militarizacije društva, po kojem je Jugoslavija postala jedna od vodećih država u Europi, a vjerojatno i šire. Istovremeno je problematizirana

117 NIKEZIĆ, „Koncepcija, doktrina i sistem opštenarodne odbrane u periodu od 1958. do 1968. godine", 217 .

118 BEBLER, „Razvitak jugoslavenske vojne doktrine”, 126.

119 MARIJAN, Slom Titove armije, 172.

${ }^{120}$ MAMULA, Slučaj Jugoslavija, 46. 
i sigurnosna funkcija društva koja je, u skladu s pojmom podruštvljavanja, postupno prozvana društvenom samozaštitom. Ključni poticaj za njezino političko definiranje dao je upad naoružane skupine hrvatskih revolucionara Feniks u ljeto 1972. godine. Nakon uništenja skupine potaknut je intenzivan rad i na društvenoj samozaštiti, koja se kao i općenarodna obrana organizirala na svim razinama društva, ali uz velike probleme zbog nerazumijevanja i loših iskustava sa sustavom državne sigurnosti do 1966. godine. Zajedno su te dvije zaštitne funkcije tumačene podruštvljavanjem poslova obrane i zaštite. Stječe se dojam da je ideal podruštvljavanja bio ideološki svjestan komunist spreman istovremeno biti i vojnik i policajac kojega ništa ne može iznenaditi i zateći nespremna. Preopterećenost upravljačkih razina postupno je 1979. dovela do fuzije tih dvaju zaštitnih kompleksa osnivanjem komiteta za ONO i DSZ, koji su u obrambeno-zaštitnom sustavu trebali osigurati vodeću ulogu Partiji. Time je i okončana ustrojbena faza jugoslavenske obrambeno-zaštitne koncepcije.

\section{Arhivski i neobjavljeni izvori}

HR-HDA-1220-CK SKH: Hrvatska, Hrvatski državni arhiv, Zagreb, fond 1220, Centralni komitet Saveza komunista Hrvatske.

HR-HDA-1616-PSRH: Hrvatska, Hrvatski državni arhiv, Zagreb, fond 1616, Predsjedništvo Socijalističke Republike Hrvatske.

HR-SVA-RSNO: Hrvatska, Središnji vojni arhiv, fond Republičkog sekretarijata za narodnu obranu Socijalističke Republike Hrvatske.

\section{Objavljeni izvori}

Deseti kongres Saveza komunista Jugoslavije. Dokumenti. Beograd: Izdavački centar „Komunist”, 1975.

Jedanaesti kongres Saveza komunista Jugoslavije. Dokumenti. Beograd: Izdavački centar „Komunist”, 1978.

\section{Službeni tisak}

Službeni list SFRJ (Beograd), 1969, 1971, 1973.

Službeni vojni list (Beograd), 1975.

\section{Interne i povjerljive tiskovine}

17. sednica CK SKJ. Ostvarivanje stavova 11. kongresa SKJ o opštenarodnoj odbrani i društvenoj samozaštiti. Beograd: Izdavački centar „Komunist”, 1981.

BAKARIĆ, Vladimir. „Aktuelna idejna i politička pitanja organiziranja i ostvarivanja društvene samozaštite", uvodno izlaganje na 13 . sjednici PCKSKJ 9. 7. 1975. U: Društvena samozaštita. Politički dokumenti i savezni i republički zakonski propisi. Zagreb: Zavod za općenarodnu obranu i društvenu samozaštitu, 1976, 35-45. 
BROZ TITO, Josip. „Učesnicima simpozijuma 'Teritorijalna odbrana u našem sistemu opštenarodne odbrane”" U: Simpozijum. Teritorijalna odbrana u našem sistemu opštenarodne odbrane. Zbornik radova, knj. I. Beograd: Državni sekretarijat za narodnu odbranu, 1970, IX-X.

DALJEVIĆ, Milan. Armija i njeno mesto u savremenom društvu. Beograd: Uprava za MPV, 1964.

Deseta sednica CK SKJ. Beograd: „Komunist”, 1968.

Društvena samozaštita. Politički dokumenti i savezni i republički zakonski propisi.Zagreb: Zavod za općenarodnu obranu i društvenu samozaštitu, 1976.

Dvadesetsedma sednica Predsedništva CKSKJ. Razvoj društvene samozaštite i zadaci Saveza komunista. Beograd, 1977.

LJUBIČIĆ, Nikola. Diskusija na 18. sjednici PCKSKJ 2. 6. 1971. U: Osamnaesta sednica Predsedništva Saveza komunista Jugoslavije. Aktuelna pitanja svenarodne odbrane. Beograd: „Komunist”, 1971, 72-86.

MAMULA, Branko. „Predgovor ediciji ‘Razvoj oružanih snaga SFRJ 19451989'”. U: Razvoj oružanih snaga SFRJ 1945-1989. Koncepcija, doktrina i sistem opštenarodne odbrane. Beograd: Vojnoizdavački i novinski centar, 1989, 5-31.

NIKEZIĆ, Ilija. „Koncepcija, doktrina i sistem opštenarodne odbrane u periodu od 1958. do 1968. godine”. U: Razvoj oružanih snaga SFRJ 1945-1989. Koncepcija, doktrina i sistem opštenarodne odbrane. Beograd: Vojnoizdavački i novinski centar, 1989, 181-272.

NOVOSEL, Đorđo. „Rad Saveznog sekretarijata za narodnu odbranu od 1968. do 1985. godine”. U: Razvoj oružanih snaga SFRJ 1945-1985. Savezni sekretarijat za narodnu odbranu. Beograd: Vojnoizdavački i novinski centar, 1990, I, 261-370.

Općenarodna obrana, sigurnost $i$ društvena samozaštita - integralni dio socijalističkog samoupravnog sistema. Zagreb: Centar CK SKH za idejno-teorijski rad, svibanj 1976.

Općenarodna odbrana i društvena samozaštita u funkciji zaštite ustavnog poretka i obrane nezavisnosti i teritorijalnog integriteta SFR Jugoslavije. Prosinac 1978.

Osamnaesta sednica Predsedništva Saveza komunista Jugoslavije. Aktuelna pitanja svenarodne odbrane. Beograd: „Komunist”, 1971.

„Predgovor”. U: Simpozijum. Teritorijalna odbrana u našem sistemu opštenarodne odbrane. Zbornik radova, knj. I. Beograd: Državni sekretarijat za narodnu odbranu, 1970, V.

PRELEVIĆ, Miloš. „Klasici marksizma o organizovanju socijalističke društvene zajednice za oružanu borbu”. U: Simpozijum. Teritorijalna odbrana u našem sistemu opštenarodne odbrane. Zbornik radova, knj. I. Beograd: Državni sekretarijat za narodnu odbranu, 1970, 20-32.

Savremena vojno-politička situacija u svetu $i$ vojno-strategijski položaj naše zemlje. II uprava GŠ JNA, str. pov. 1 od 4. 1. 1967. 
TODOROVIĆ, Boško. „Koncepcija, doktrina i sistem opštenarodne odbrane u periodu od 1968. do 1985. godine". U: Razvoj oružanih snaga SFRJ 1945-1985. Koncepcija, doktrina i sistem opštenarodne odbrane. Beograd: Vojnoizdavački i novinski centar, 1989, 273-388.

ŽIVKOVIĆ, Miljenko. Razvoj oružanih snaga SFRJ 1945-1985. Teritorijalna odbrana. Beograd: Vojnoizdavački i novinski centar, 1986.

\section{Literatura}

ATELJEVIĆ, Milan; PETKOVIĆ, Aleksandar. Komiteti za opštenarodnu odbranu i društvenu samozaštitu. Beograd: NIO Poslovna politika, 1985.

BEBLER, Anton. „Razvitak jugoslavenske vojne doktrine”. Politička misao 22 (1985), br. 4: 123-141.

BROZ TITO, Josip. „Aktuelni unutrašnji i međunarodni problem i uloga SKJ u socijalističkom sistemu samoupravljanja”. U: Deveti kongres Saveza komunista Jugoslavije. Dokumenti. Beograd: „Komunist”, 1969, 49-112.

BROZ TITO, Josip. „Borba za dalji razvoj socijalističkog samoupravljanja u našoj zemlji i uloga SKJ”. U: Deseti kongres Saveza komunista Jugoslavije. Dokumenti. Beograd: Izdavački centar „Komunist”, 1975, 9-58.

BROZ TITO, Josip. „Iskustva narodnooslobodilačke borbe i sistem opštenarodne odbrane". U: Opštenarodna odbrana Jugoslavije, ur. Olga Mladenović. Beograd: Međunarodna politika, 1970, 15-22.

BROZ TITO, Josip. O opštenarodnoj odbrani. Beograd: Slovo ljubve, 1976.

BROZ TITO, Josip. Opštenarodna odbrana i društvena samozaštita. Sarajevo: Vojnoizdavački zavod; „Svjetlost”; Državna založba Slovenije; „Mladost”; „Prosveta”; „Pobjeda”; Matica srpska, 1980.

BROZ TITO, Josip. „SKJ u borbi za dalji razvitak socijalističke, samoupravne i nesvrstane Jugoslavije”. U: Jedanaesti kongres Saveza komunista Jugoslavije. Dokumenti. Beograd: Izdavački centar „Komunist”, 1978, 13-62.

Društvene osnove opštenarodne odbrane. Beograd: Politička škola JNA, 1970.

GOLDSTEIN, Ivo; GOLDSTEIN, Slavko. Tito. Zagreb: Fraktura, 2015.

GRDEŠIĆ, Ivan; JANTOL, Tomislav; KASAPOVIĆ, Mirjana; PERKO-ŠEPAROVIĆ, Inge; ŠIBER, Ivan; TOMAC, Zdravko. Delegatski sistem 1974-1984. Zagreb: Informator; Fakultet političkih nauka Sveučilišta u Zagrebu, 1986.

KLASIĆ, Hrvoje. Jugoslavija i svijet 1968. Zagreb: Naklada Ljevak, 2012.

KOREN, Snježana. Politika povijesti u Jugoslaviji (1945-1960). Komunistička partija Jugoslavije, nastava povijesti, historiografija. Zagreb: Srednja Europa, 2012.

LJUBIČIĆ, Nikola. „Opštenarodna odbrana Jugoslavije”. U: Opštenarodna odbrana u teoriji i praksi izmedu IX i X kongresa SKJ. Beograd: „Narodna armija”, 1974, 36-74. 
MAMULA, Branko. Slučaj Jugoslavija. Podgorica: CID, 2000.

MARIJAN, Davor. Slom Titove armije. JNA i raspad Jugoslavije 1987. 1992. Zagreb: Golden marketing - Tehnička knjiga; Hrvatski institut za povijest, 2008.

MIHALJEVIĆ, Josip. Komunizam i čovjek. Odnos vlasti i pojedinca u Hrvatskoj (1958. - 1972.). Zagreb: Hrvatski institut za povijest, 2016.

MIŠKOVIĆ, Ivan; MANDIĆ, Mile. Civilna zaštita u SFRJ. Beograd: Poslovna politika, 1987.

NINKOVIĆ, Jovo. Karakter i osobenosti razvoja ratne veštine narodnooslobodilačkog rata u Jugoslaviji 1941-1945. Beograd: Vojnoizdavački i novinski centar, 1989.

RADELIĆ, Zdenko. Hrvatska u Jugoslaviji 1945. - 1991. Od zajedništva do razlaza. Zagreb: Školska knjiga; Hrvatski institut za povijest, 2006.

RADIĆ, Aleksandar. „Vežba Avala - Jugoslovenska odbrana od Varšavskog pakta 1968. godine”. Istorija 20. veka XXIV (2006), br. 2: 87-104.

RIBIČIČ, Mitja. „O koncepciji opštenarodne odbrane”. Vojno delo XXI (1969), br. 2: 4-8.

RUKAVINA, Ivan. „O općenarodnoj obrani”. Predavanje na seminaru o pripremama stanovništva za općenarodnu obranu i zaštitu održanom u Crikvenici 25. rujna 1968. Zagreb: Republička konferencija Socijalističkog saveza radnog naroda Hrvatske, rujan 1968.

SIKIMIĆ, Borislav. Odbrana u ustavnom sistemu SFRJ. Beograd: VIZ, 1985.

TODOROVIĆ, Boško; VILIĆ, Dušan. Vanredne prilike. Beograd: Privredapublik, 1989.

TUBIĆ, Risto. Enciklopedijski rječnik marksističkih pojmova. Sarajevo: „Veselin Masleša”, 1974. 


\section{The Conception of Total People's Defence and Social Self-Protection: The Militarism of Self-Governing Socialism}

The conception of total people's defence and social self-protection, as the Yugoslav defence-protection system was called, began to be implemented after the Warsaw Pact countries' invasion of Czechoslovakia in August 1968. Yugoslav communists believed that this sudden and successful aggression could be effectively opposed only through the organised engagement of all available societal potentials, based on its revolutionary experience and reflections on Marxist classics regarding arming the populace. This was the beginning of a conception of defence that visibly burdened the society, increased the already large military budget, and prompted the militarisation of society. Although the security of society, called social self-protection, was discussed at the same time as defence, the true impetus for its theoretical and practical formation was the infiltration of the paramilitary cell Feniks (Phoenix) into Yugoslavia in summer 1972. In contrast to total people's defence, whose implementation was considered successful, the implementation of social self-protection ran into numerous problems because security was from 1945 to 1966 exclusively the responsibility of the security service, and therefore difficult to accept in other social structures. For this reason, on several occasions the League of Communists initiated its acceptance on all levels of organisation in party and social-political structures. A relatively efficient fusion of these two protective complexes was achieved only in 1979, after the founding of committees for total people's defence and social self-protection, which were supposed to secure the leading role of the League of Communists of Yugoslavia in the defence-security system.

Key words: Yugoslavia; Croatia; League of Communists; defence; security; militarism 